\title{
Organic geochemical and petrographical characteristics of the major lower cretaceous petroleum source rock (Makhul Formation) in Kuwait - Arabian Gulf
}

\author{
Fatma K. Bahman ${ }^{1,}$, Fowzia H. Abdullah ${ }^{2}$, Abbas Saleh $^{3}$, Hossein Alimi ${ }^{4}$ \\ 1, 2, ${ }^{3}$ Earth and Environmental Sciences Dept. Kuwait University, 72303, Kuwait \\ ${ }^{4}$ Mark Family Dept. of Chemical Engineering and Material Science, \\ University of Southern California, CA94501, USA \\ *Corresponding author: fatmah.bahman@ku.edu.kw
}

\begin{abstract}
The Lower Cretaceous Makhul Formation is one of the major petroleum source rocks in Kuwait. This study aims to evaluate the Makhul source rock for its organic matter richness and its relation to the rock composition and depositional environment. A total of 117 core samples were collected from five wells in Raudhatain, Ritqa, Mutriba, Burgan, and Minagish oil fields north and south Kuwait. The rock petrographical studies were carried out using a transmitted and polarized microscope, as well as SEM and XRD analyses on selected samples. Total organic matter TOC and elemental analyses were done for kerogen type optically. The GC and GC-MS were done as well as the carbon isotope ratio.

The results of this study show that at its earliest time the Makhul Formation was deposited in an anoxic shallow marine shelf environment. During deposition of the middle part, the water oxicity level was fluctuating from oxic to anoxic condition due to changes in sea level. At the end of Makhul and the start of the upper Minagish Formation, the sea level raised forming an oxic open marine ramp depositional condition.

Organic geochemical results show that the average TOC of the Makhul Formation is $2.39 \%$ wt. High TOC values of $6.7 \%$ wt. were usually associated with the laminated mudstone intervals of the formation. The kerogen is of type II and is dominated by marine amorphous sapropelic organic matter with a mixture of zoo- and phytoplankton and rare terrestrial particles.

Solvent extract results indicate non-waxy oils of Mesozoic origin that are associated with marine carbonate rocks. The formation is mature and at its peak oil generation in its deepest part in north Kuwait.
\end{abstract}

Keywords: Cretaceous; Makhul Formation; organic geochemistry; Petroleum Geology; source rocks.

\section{Introduction}

The Lower Cretaceous interval in Kuwait extends from 1158.5 to $1341.5 \mathrm{~m}$ depth where it thickens toward the NNE of Kuwait and towards the Mesopotamian Basin (Al-Fares et al., 1998). During Early Cretaceous, Kuwait was located on the differentiated southern passive margin of Neo Tethys comprising shallow-water shelves and deeper-water intra-shelf basins 
(Murris, 1980). The location of the shelf-to-basin transition oscillated through time because of eustatic sea-level changes. In Kuwait, the Lower Cretaceous Thamama Group (Berriasian to Aptian) is the carbonate dominant group. It is divided from the bottom into Makhul, Minagish, Ratawi, Zubair, and Shu'aiba Formations (Murris, 1980; Alsharhan \& Nairn, 1997) (Figure 1a). The lower part of the group, Makhul, Minagish, and Ratawi Formations, is composed of neritic limestone and shale with thin sandstones, while the uppermost part is composed of limestone and dolomitic limestone. A thick sandstone interval with shale and minor siltstones, Zubair Formation, is sandwiched between these two carbonate-dominated successions which were deposited during short-term tectonic uplift of the Arabian Shield (Beydoun, 1991 \& Warsi 1989).

The Makhul Formation straddles the Jurassic/Cretaceous Boundary in Kuwait and is underlain by the Hith Anhydrite and overlain by the Minagish Formation (Figure 1a) (Al-Rifaiy $\&$ Lemone, 1987). The formation corresponds to the Sulaiy Formation in most of the Arabian Gulf region countries. The Cretaceous sequence in the Arabian plate is referred to as AP8 Late Jurassic (Tithoninan) to Middle Cretaceous (Turonian) (Alsharhan et al., 2014).

Makhul Formation is composed of lime mudstones which are locally dolomitic and anhydritic and are interbedded with marl and silt beds. Its lithology varies across Kuwait from fine-grained limestone in the south to interbedded fine-grained limestone and shale elsewhere (Hussain, 1983). The thickness of the formation in Kuwait ranges between $91 \mathrm{~m}$ to $335.3 \mathrm{~m}$ where it thickens towards NW Kuwait (Figure 1b). The formation was deposited on a ramptype carbonate platform which deepened to the east into the Neo Tethys Ocean (Murris, 1980; Beydoun, 1991; Alsharhan \& Nairn, 1997). Bioclastic material in the formation includes sponge spicule, radiolarians, coccoliths, echinoids, and foraminifera, together with pellets and other organic particles indicating a deep marine depositional setting at sometimes of its depositional intervals (Alsharhan \& Nairn, 1997).

Makhul Formation is considered as one of the best Mesozoic source rocks in Kuwait (Abdullah \& Kinghorn, 1996; Abdullah et al., 1997, Abdullah et al., 2005). It is widely distributed as a rich source rock in the Arabian Gulf region such as Iraq, Saudi Arabia, Qatar, Bahrain, Dubai, and offshore Abu Dhabi (Beydoun, 1991; Alsharhan \& Nairn, 1997; Hans, 1984). The formation locally contains high TOC intervals in Saudi Arabia (Ayres et al., 1982). In southern Iraq, the TOC content ranges between 0.5 and $1 \%$ wt with Type-II kerogen (AlAmeri et al., 1999).

Preliminary studies have shown that Makhul Formation is good to very good source rock containing marine Type II kerogen (Abdullah \& Kinghorn, 1996; Abdullah \& Connan, 2002). Using log analysis, Hussain (1983) recorded TOC contents of up to $10.1 \%$ wt. Thermal modeling (Abdullah et al., 1997) showed that the formation reached its peak oil generation stage in the Late Cretaceous (75 Ma). Recent studies show Makhul Formation is an unconventional reservoir in some of the oil fields in Kuwait (Arasu et al., 2012).

This study examines the petrography and depositional environment condition of the Makhul Formation in Kuwait. The result is correlated with the nature and amount of organic matter as well as its maturity level to evaluate its source rock potential. 


\section{Materials and methods}

A total of 117 core samples from the Makhul Formation from five oilfields in Kuwait (Figure 1b) were supplied by the Kuwait Oil Company (KOC). The selected oilfields are Raudhatain (RA), Ritqa (RQ), and Mutriba (MU) in the north (Figure 1c), and Burgan (BG), and Minagish $(\mathrm{MN})$ in the south of Kuwait (Figure 1d). The visual examination of the core samples was carried out and correlated with Gamma Ray logs.

A total of 60 thin sections were studied using transmitted and polarized light microscopy and some of them were color stained for carbonate identification (Emery \& Robinson, 1993). Ten core samples from northern oilfields were examined by X-Ray Diffraction (XRD) (X-Ray diffractometer, D5000 Siemens with $2 \varnothing$ ranges from $10^{\circ}-80^{\circ}$, step size (SS) $=0.014 \mathrm{dg}$ and step time $(\mathrm{CT})=0.2 \mathrm{~s})$.

The total organic carbon (TOC) content for 37 samples of Makhul Formation from Mutriba oilfield north Kuwait was measured using LECO CHNS-932 Elemental Analyzer. The samples were taken from the bottom to the top (every half to 1 meter) along the formation. However, due to the limited availability of samples in the other four oilfields, 17 samples were collected from the north (Ritqa and Raudhatain) and south Kuwait (Burgan and Minagish). Four samples from middle and top Ritqa, 4 samples from middle Raudhatain, 5 samples from bottom Burgan, and 4 samples from middle Minagish. These samples were treated by pyrolysis Rock-Eval 6 (REO), using standard bulk rock method, which the sample is heated at $300^{\circ} \mathrm{C}$ for $5 \mathrm{~min}$., followed by the heating ramp of $300-650^{\circ} \mathrm{C}$ at a rate of $25^{\circ} \mathrm{C} /$ minute (Peters, 1986; Shah \& Ahmed, 2018; Shah \& Ahmed, 2020). For kerogen elemental analyses and kerogen isolation examination, the samples were treated using standard acid maceration techniques using HCL and HF to calculate the amount of TOC contents, and the type of the organic matter as well as an environment of deposition,

The kerogen residue was treated with 2.24 specific gravity Zinc Bromide $\left(\mathrm{ZnBr}_{2}\right)$ to remove insoluble heavy minerals such as pyrite (Kinghorn \& Rahman, 1983). The kerogen residues were mounted in glycerine and examined under the transmitted light microscope. Some of the heavy kerogen residual remains were mounted on stubs and coated with gold to be examined by Scanning Electron Microscope (SEM) (JEOL'S JSM-6300).

Four samples extracted from the Mutriba oilfield were chosen and prepared later for organic geochemical examinations by the Weatherford Labs. Bitumen extraction was done using a Soxhlet extractor on Pulverized rock samples using methylene chloride as an organic solvent. The isolated extracts (bitumen) were concentrated and quantitatively determined as weight \% (or ppm). Saturated and aromatic fractions of the bitumen extracts were separated for GC-MS analysis using column chromatography. The extracts were further analysed by high-resolution GC to determine the hydrocarbon compositions. Saturate and aromatic biomarkers were investigated using GC-MS. Stable carbon isotope ratios $\left(\delta^{13} \mathrm{C}\right)$ were analysed for both rock extracts as well as saturate and aromatic fractions. 


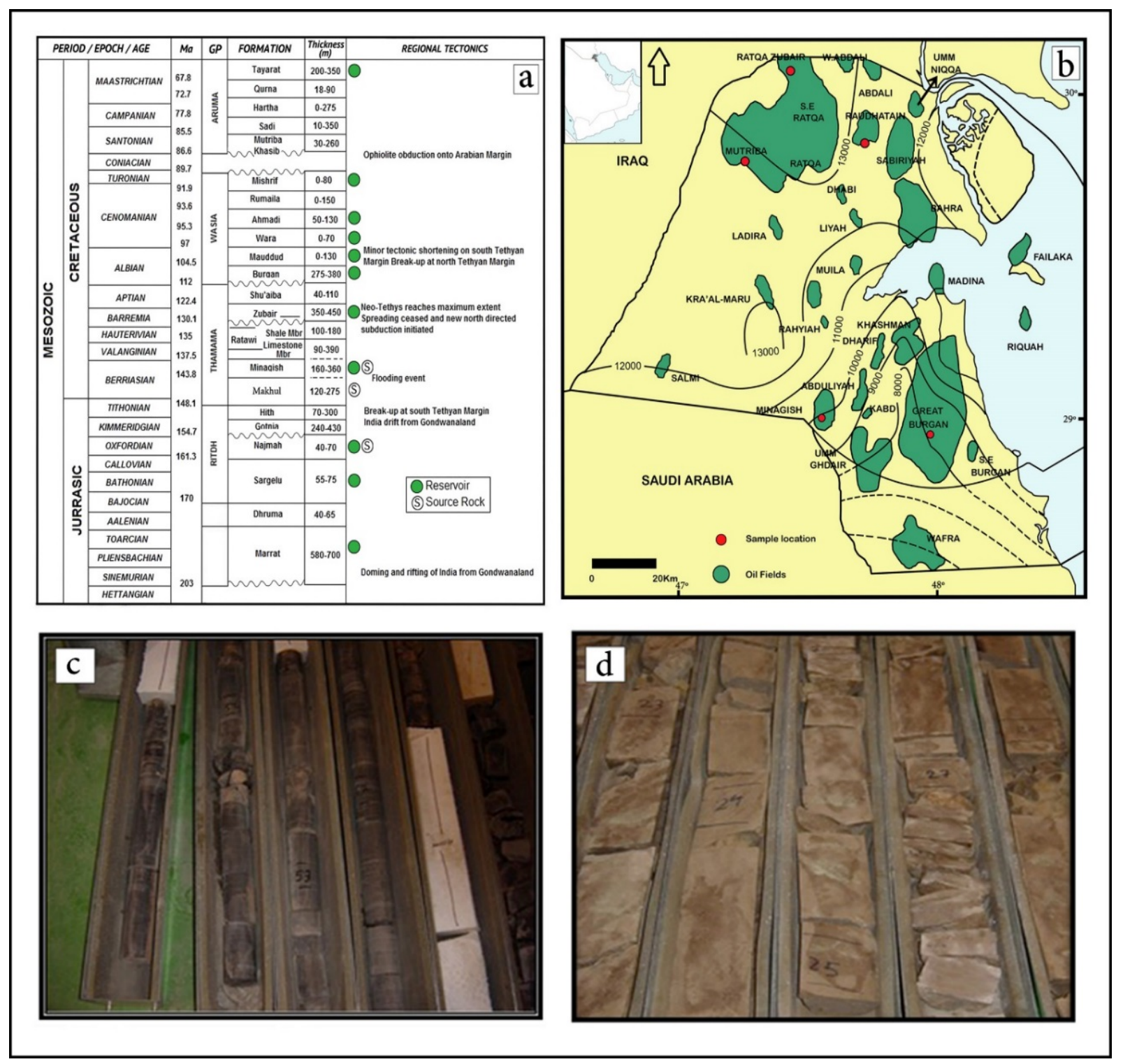

Fig. 1. (a) Stratigraphic column for the Mesozoic succession in Kuwait showing the Lower Cretaceous Makhul Formation, the focus of this study (after Abdullah et al., 1997), (b) Structural contour map (by feet) of the top-Makhul Formation in Kuwait (well location shows data points provided),(c) Core of the Makhul Formation from Raudhatain field in north Kuwait showing the general features of the dark grey carbonate with laminar structure, (d) Core of the Makhul Formation from Minagish field in south Kuwait showing light grey massive carbonate structure.

\section{Results}

\subsection{Lithostratigraphy, Petrology and Minerals contents}

The Makhul Formation has a maximum thickness of 335.3 meters in northwest Kuwait and a minimum in southwest Kuwait (91.5 m).

Petrographical examination reveals that it is composed of dark grey to black, massive, and laminated lime mudstones with high organic matter contents (Table 1, Table 2, and Plate 1a). 
In some parts, the Makhul Formation is packstone and grainstone (Plate 1b).

Massive limestone is commonly found in both Minagish and Burgan oilfields (Table 2 and Figure 1d) in south Kuwait. The laminated part of the formation corresponds to more than $50 \%$ of the whole section in Mutriba Field (Table 1 and Figure 1c) and covering the middle and upper parts of the formation. The thick laminated limestone section is predominantly found in the Ritqa, Raudhatain, and Mutriba fields (Table 2 and Figure 1c).

The lower part of the Makhul Formation is light grey, massive, fine-grained limestone mixed with anhydrite (Plate 1c). It has a low content of bitumen compared to its upper parts. It gradually changes upward to a dark grey to black, fine-grained, highly bituminous laminated limestone in its middle part (Plate 1d). At its top parts, the Makhul, changes to grey, massive, fine-grained limestone with its upper contact with Minagish Formation (Table 1 and Plate 1e). The XRD results show that the Makhul Formation is dominated by calcite $(>80 \%)$ with minor quartz ( $8 \%$ ), dolomite, gypsum, kaolinite, and ankerite (Table 3). The gypsum mineral is found in higher proportions in the deepest parts, where the formation is mixed with the upper Hith Anhydrite, (MU/27, 4087m) contains gypsum of 3.8\%. While the clay minerals are found in higher proportions in the middle parts, $(\mathrm{RQ} / 5,4390.6 \mathrm{~m})$ kaolinite $7.1 \%$ and ankerite $5 \%$, where the laminated carbonate is abundant in the north oilfield. The quartz content is higher in the middle parts, $(\mathrm{RQ} / 5,4390.6 \mathrm{~m})$ contains Quartz 10.2\%, where more sponge spicules are associated with laminated carbonate, especially in the northern oilfields (Table 3).

The laminated parts of the Makhul Formation contain large collections of sponge spicules, radiolarians (Plate 1f), foraminifera, coccoliths (Plate 1g), echinoids, and other microbial particles (organic matter). Some of these particles were completely replaced by pyrite crystals by the process of pyritization (Plate $1 \mathrm{~h}$ and Plate $2 \mathrm{a}, \mathrm{b}, \mathrm{c}, \mathrm{d}$ ). Plate $2 \mathrm{f}$ shows the pyritized foraminifera cast coated by a film of kerogen.

Microscopic results, as well as SEM studies, show the presence of abundant framboidal pyrite crystals (Plate 2e) with cubic euhedral, and subhedral crystals which are commonly found in micritic mudstones rocks (Plate 1c). Compared to the north part of Kuwait, the south and southwest fields show courser-grained limestone with fewer sponge spicules and foraminifera (Plate 1e).

\subsection{Organic Geochemistry}

The total organic carbon (TOC) results are relatively high in all the studied oilfields (Table 1 and Table 2). The average TOC value in the northern oilfields is $3.10 \%$ wt. In Mutriba the average value is $1.67 \% \mathrm{wt}$. (Table 1), in Ritqa is $2.28 \% \mathrm{wt}$., and in Raudhatain is $1.81 \% \mathrm{wt}$. (Table 2). The highest value of TOC in northern oilfields is found in the Mutriba oilfield (4.85\% wt.). Whereas the average TOC in the southern oilfields is $1.92 \%$ wt. In Burgan, the average value is $2.07 \%$ wt. while it is $4.12 \%$ wt in Minagish Field. The highest TOC value in southern oilfields is found in Minagish (6.7\%wt.) (Table 2).

The organic matter size in Makhul Formation is relatively large to moderate amorphous marine particles which are predominantly concentrated and associated in the laminated intervals of the formation (Plate 3a). They change in size along with the formation from fine at the lower part (Plate $3 b$ ) to moderate-coarse at the middle to fine amorphous particles at its upper part (Table 4). 
The kerogen particles found in the middle interval contain different types of well-preserved zoo- and phytoplankton where their colours are well-identified in Table 4. Filamentous algae of brown colour are the most abundant organic matter in the middle part (Plate 3c). Marine pollen grains and spores are commonly displaying brown colour and usually well preserved with rounded, clear edges, and intact cell walls in the middle part of the formation (Plate 3d). Foraminifera (Plate 3e) of yellow to light brown colour with some terrigenous organic matter such as pollen, resins, woody particles, cuticles, some plant tissues, and rare vitrinite is found in the uppermost part as well as the deeper part of the formation (Plate $3 \mathrm{f}, \mathrm{g}$, and $\mathrm{h}$ ). Most of the spores are yellow to brown, well preserved in the middle part except for rare dark brown colour found at the upper and deeper parts of the formation at its lower boundaries with Hith Formation (Plate 3i and j) (Table 4).

In the northern oilfields, the TOC varies with depth and lithology. The samples with more marl and mud content, clear lamination, and fine texture limestone have high TOC content. The TOC increases in the middle part of the formation and decreases at the shallower and deeper parts. In Mutriba oilfield, the deepest depth intervals (MU/11, 4155.2m) has 0.74 TOC \%wt., and at the middle part of the formation, (MU/46, 4066m) has 4.13 TOC \%wt., whereas it decreases at the shallowest part (MU/84, 3998.5m) 0.42 TOC \%wt. (Table 1). In the Ritqa oilfield, the middle part contains high TOC (RQ/6, 4389.9m) 2.97 TOC \%wt., while it decreases at the shallowest part (RQ/18, 4378.6m) 1.91 TOC \%wt. (Table 2). In the Raudhatain oilfield, the middle part, $(\mathrm{RA} / 2,3809.1 \mathrm{~m})$ contains 2.9 TOC \%wt.

In the southern oilfields, at the deepest part of Burgan oilfield, (BG/14, 2638.7m) contains 1.42 TOC \% wt. In the Minagish oilfield, the middle part (MN/3, 3104.5m) contains high TOC (6.7 TOC \%wt.) (Table 2).

In general, in all the studied oilfields it is obvious that the high TOC is found in the middle part of the formation and is associated with the laminated fine-grain mudstone. On the other hand, the low TOC content is associated with the massive limestone at the upper part of the formation with its contacts with Minagish Formation and in the lower part contact where the formation is mixed with the anhydrite Hith Formation (Tables 1 and 2).

\subsubsection{Pyrolysis Results}

The RE6 results for 17 samples in four oilfields in northern and southern Kuwait are shown in Table 2. The Hydrogen Index (HI) ranges between 6 - $542 \mathrm{mg} \mathrm{HC} / \mathrm{g}$ TOC, the Tmax ranges between 423 - $446 \mathrm{C}^{\circ}$, and the oxygen index (OI) ranges between 6 - $96 \mathrm{mg} \mathrm{CO} / \mathrm{g}$ TOC. These results are shown in the plot diagrams in Figures $2 \mathrm{a}$ and $2 \mathrm{~b}$. The Hydrogen Index (HI) is increasing with increasing of depth, $(\mathrm{BG} / 18,2635.9 \mathrm{~m})$ reaching $432 \mathrm{HI}$ value, and (BG/14, $2638.7 \mathrm{~m}$ ) contains $449 \mathrm{HI}$ value. While the Oxygen Index (OI) is decreasing with increasing of depth, (BG/18, 2635.9m) contains 26 OI value, and (BG/14, 2638.7m) contains 6 OI value. The Tmax values are relatively high in the middle parts at the southern oilfields, (MN/3, 3104.5m), getting at $446 \mathrm{C}^{\circ}$ Tmax value, and $(\mathrm{RQ} / 18,4378.6 \mathrm{~m}) 440 \mathrm{C}^{\circ} \operatorname{Tmax}$ value at the northern oilfields. 
Table 1. The total organic carbon (TOC) by LECO for 37 core samples of Makhul Formation in Mutriba oilfield (MU), north Kuwait.

\begin{tabular}{|c|c|c|c|c|c|}
\hline \multirow[t]{2}{*}{ Samples } & \multirow{2}{*}{$\begin{array}{l}\text { Depth } \\
\text { (m) }\end{array}$} & \multirow[t]{2}{*}{ Rock Description } & \multirow{2}{*}{$\begin{array}{l}\text { TOC } \\
\% \text { wt. }\end{array}$} & \multicolumn{2}{|c|}{$\begin{array}{l}\text { Isolated } \\
\text { Kerogen }\end{array}$} \\
\hline & & & & $\mathbf{H} / \mathbf{C}$ & $\mathrm{O} / \mathrm{C}$ \\
\hline $\mathrm{MU} / 84$ & 3998.5 & \multirow{2}{*}{$\begin{array}{l}\text { Dark grey to black massive } \\
\text { carbonate with pyrite }\end{array}$} & 0.42 & 1.01 & 0.05 \\
\hline MU/81 & 4002.1 & & 0.88 & 1.07 & 0.04 \\
\hline $\mathrm{MU} / 78$ & 4003.9 & $\begin{array}{l}\text { Dark grey to black laminated } \\
\text { carbonate with dolomite }\end{array}$ & 1.78 & & \\
\hline $\mathrm{MU} / 75$ & 4007.6 & \multirow{9}{*}{$\begin{array}{l}\text { Dark grey to black laminated } \\
\text { carbonate with pyrite }\end{array}$} & 1.36 & & \\
\hline $\mathrm{MU} / 72$ & 4010.3 & & 1.44 & & \\
\hline $\mathrm{MU} / 71$ & 4011.2 & & 2.02 & 1.09 & 0.05 \\
\hline $\mathrm{MU} / 69$ & 4013.7 & & 1.04 & & \\
\hline MU/67 & 4016.7 & & 1.54 & & \\
\hline MU/64 & 4020.4 & & 1.42 & & \\
\hline $\mathrm{MU} / 62$ & 4022.8 & & 1.37 & & \\
\hline $\mathrm{MU} / 60$ & 4025.3 & & 0.21 & & \\
\hline $\mathrm{MU} / 58$ & 4027.7 & & 0.45 & 1.1 & 0.08 \\
\hline $\mathrm{MU} / 56$ & 4057 & \multirow{2}{*}{$\begin{array}{l}\text { Dark grey to black massive } \\
\text { carbonate with pyrite }\end{array}$} & 1.82 & 1.14 & 0.09 \\
\hline $\mathrm{MU} / 54$ & 4057.9 & & 2.33 & & \\
\hline $\mathrm{MU} / 52$ & 4059 & $\begin{array}{l}\text { Grey carbonate with thick } \\
\text { lamination and pyrite }\end{array}$ & 2.64 & & \\
\hline $\mathrm{MU} / 50$ & 4061.2 & \multirow{2}{*}{$\begin{array}{l}\text { Light grey massive carbonate with } \\
\text { sponge spicules }\end{array}$} & 2.49 & & \\
\hline $\mathrm{MU} / 48$ & 4063.7 & & 3.4 & & \\
\hline $\mathrm{MU} / 47$ & 4064.9 & \multirow{2}{*}{$\begin{array}{l}\text { Dark grey to black laminated } \\
\text { carbonate pyrite rich }\end{array}$} & 2.79 & & \\
\hline $\mathrm{MU} / 46$ & 4066 & & 4.13 & 1.08 & 0.06 \\
\hline $\mathrm{MU} / 44$ & 4068.5 & \multirow{3}{*}{$\begin{array}{l}\text { Dark grey carbonate with clear } \\
\text { thick lamination }\end{array}$} & 3.12 & & \\
\hline $\mathrm{MU} / 42$ & 4071 & & 1.84 & & \\
\hline $\mathrm{MU} / 40$ & 4073.4 & & 1.12 & & \\
\hline $\mathrm{MU} / 38$ & 4075.9 & \multirow{7}{*}{ Dark grey massive carbonate } & 1.33 & & \\
\hline $\mathrm{MU} / 36$ & 4078.3 & & 0.24 & 1.14 & 0.08 \\
\hline $\mathrm{MU} / 34$ & 4080.7 & & 1.02 & & \\
\hline $\mathrm{MU} / 32$ & 4083.2 & & 0.92 & & \\
\hline $\mathrm{MU} / 30$ & 4085.7 & & 1.26 & 1.08 & 0.09 \\
\hline $\mathrm{MU} / 28$ & 4087.2 & & 2.61 & & \\
\hline $\mathrm{MU} / 26$ & 4089.3 & & 1.28 & & \\
\hline $\mathrm{MU} / 23$ & 4092.9 & \multirow{2}{*}{ Light grey laminated carbonate } & 1.74 & & \\
\hline $\mathrm{MU} / 21$ & 4095.4 & & 2.25 & & \\
\hline MU/18 & 4098.7 & \multirow{6}{*}{$\begin{array}{l}\text { Dark grey to black laminated } \\
\text { carbonate }\end{array}$} & 4.85 & 1.13 & 0.06 \\
\hline $\mathrm{MU} / 16$ & 4149.7 & & 0.29 & 0.84 & 0.07 \\
\hline $\mathrm{MU} / 14$ & 4152.1 & & 1.1 & & \\
\hline $\mathrm{MU} / 12$ & 4154.5 & & 1.07 & & \\
\hline $\mathrm{MU} / 11$ & 4155.2 & & 0.74 & & \\
\hline $\mathrm{MU} / 10$ & 4156.4 & & 1.47 & 0.86 & 0.06 \\
\hline
\end{tabular}


Table 2. The total organic carbon (TOC) by pyrolysis for 17 core samples of Makhul Formation in the north and south Kuwait. North fields: $(\mathrm{RQ})=$ Ritqa (4 samples) and (RA) = Raudhatain (4 samples). South fields: $(B G)=$ Burgan $(5$ samples $)$ and $(M N)=$ Minagish (4 samples)

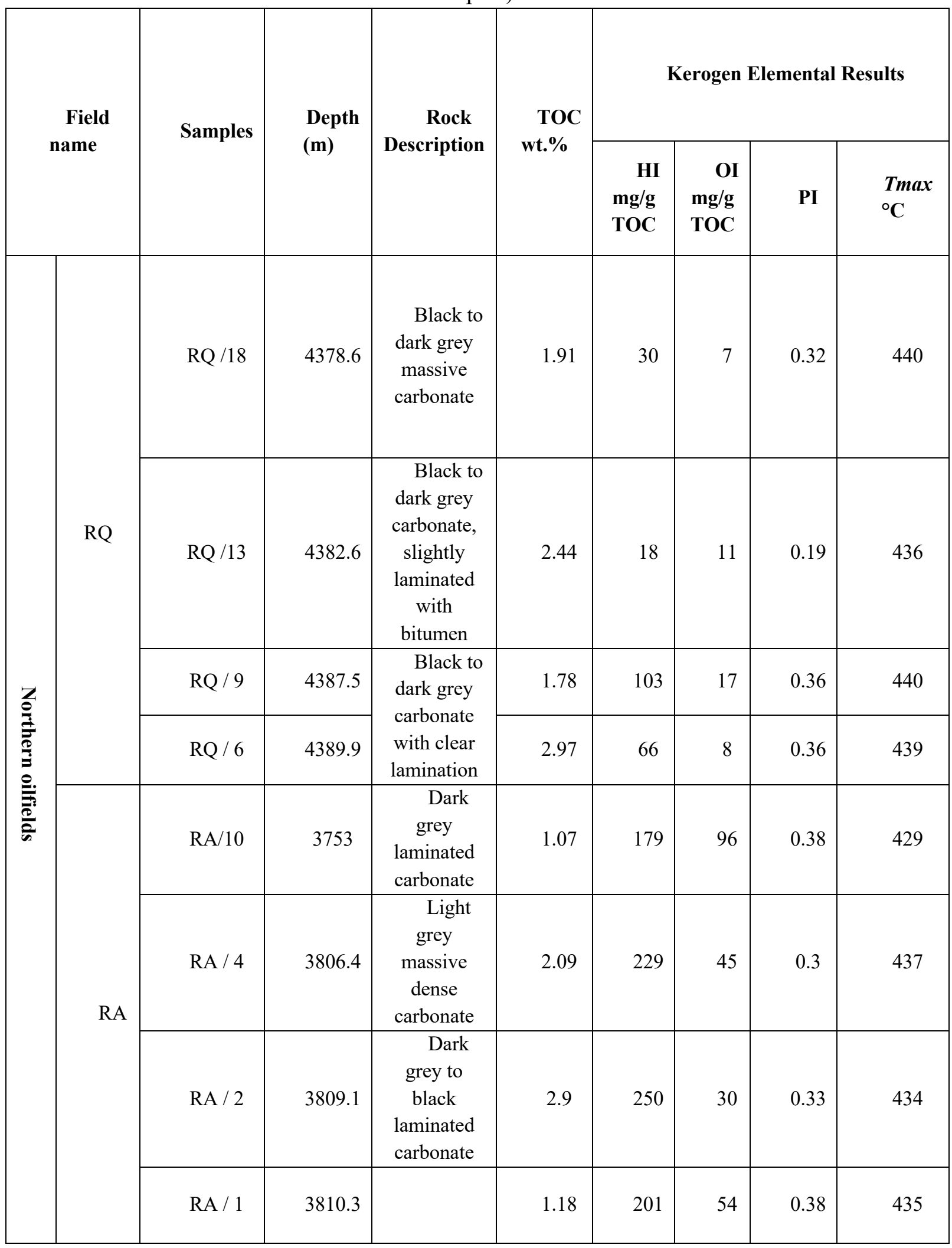




\begin{tabular}{|c|c|c|c|c|c|c|c|c|c|}
\hline \multirow{9}{*}{ 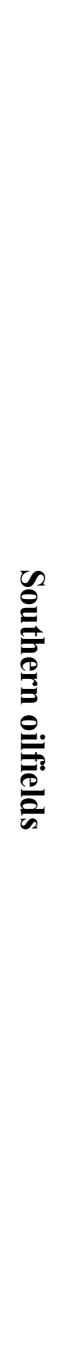 } & \multirow{5}{*}{ BG } & $\mathrm{BG} / 18$ & 2635.9 & $\begin{array}{c}\text { Black } \\
\text { massive } \\
\text { carbonate }\end{array}$ & 2.35 & 432 & 26 & 0.14 & 435 \\
\hline & & $\mathrm{BG} / 17$ & 2636.8 & \multirow{4}{*}{$\begin{array}{c}\text { Dark } \\
\text { grey } \\
\text { massive } \\
\text { carbonate } \\
\text { with thin } \\
\text { layers of } \\
\text { shale }\end{array}$} & 1.64 & 542 & 21 & 0.17 & 431 \\
\hline & & $\mathrm{BG} / 16$ & 2637.1 & & 1.67 & 432 & 36 & 0.18 & 434 \\
\hline & & $\mathrm{BG} / 15$ & 2638.1 & & 3.27 & 401 & 13 & 0.18 & 432 \\
\hline & & BG/14 & 2638.7 & & 1.42 & 449 & 6 & 0.18 & 431 \\
\hline & \multirow{4}{*}{ MN } & $\mathrm{MN} / 6$ & 3099.6 & $\begin{array}{l}\text { Light } \\
\text { brown to } \\
\text { greyish } \\
\text { massive } \\
\text { carbonate }\end{array}$ & 2.12 & 380 & 17 & 0.41 & 426 \\
\hline & & $\mathrm{MN} / 3$ & 3104.5 & $\begin{array}{c}\text { Very } \\
\text { light brown } \\
\text { to greyish } \\
\text { massive } \\
\text { carbonate }\end{array}$ & 6.7 & 50 & 5 & 0.14 & 446 \\
\hline & & $\mathrm{MN} / 2$ & 3267.9 & $\begin{array}{l}\text { Very } \\
\text { light brown } \\
\text { to greyish } \\
\text { massive } \\
\text { carbonate }\end{array}$ & 2.78 & 6 & 14 & 0 & 435 \\
\hline & & $\mathrm{MN} / 1$ & 3268.9 & $\begin{array}{l}\text { Black to } \\
\text { dark grey } \\
\text { massive } \\
\text { carbonate }\end{array}$ & 4.88 & 32 & 13 & 0.14 & 434 \\
\hline
\end{tabular}

Table 3. The average concentration of major minerals contents by XRD for 10 core samples of Makhul Formation in northern oilfields in Kuwait. (RQ)= Ritqa, $(\mathrm{RA})=$ Raudhatain, and (MU) = Mutriba

\begin{tabular}{|c|c|c|c|c|c|c|c|}
\hline Sample & $\begin{array}{l}\text { Depth } \\
\text { (m) }\end{array}$ & Calcite \% & $\begin{array}{c}\text { Quartz } \\
\text { \% }\end{array}$ & $\begin{array}{c}\text { Dolomite } \\
\text { \% }\end{array}$ & $\begin{array}{c}\text { Gypsum } \\
\text { \% }\end{array}$ & $\begin{array}{c}\text { Kaolinite } \\
\text { \% }\end{array}$ & $\begin{array}{c}\text { Ankerite } \\
\text { \% }\end{array}$ \\
\hline RQ/ 5 & 4390.6 & 76.1 & 10.2 & 1.6 & & 7.1 & 5 \\
\hline RA/3 & 3806.3 & 97.7 & 2.3 & & & & \\
\hline MU/34 & 4079.7 & 78.4 & 8.2 & 11.2 & 2.2 & & \\
\hline MU/33 & 4080.9 & 65.8 & 10.4 & 19.2 & 4.6 & & \\
\hline MU/30 & 4085.7 & 81.8 & 9.6 & 4.9 & 3.7 & & \\
\hline MU/27 & 4087 & 85 & 8.3 & 2.9 & 3.8 & & \\
\hline MU/20 & 4096.2 & 86.6 & 7.9 & & 5.5 & & \\
\hline MU/19 & 4096.8 & 71.8 & 11.3 & & & 8 & 9 \\
\hline MU/13 & 4152.2 & 92.5 & 5.2 & & 2.3 & & \\
\hline MU/10 & 4156.4 & 90.7 & 9.3 & & & & \\
\hline Avg. & & 82.6 & 8.3 & 8 & 3.7 & 8 & 7 \\
\hline
\end{tabular}




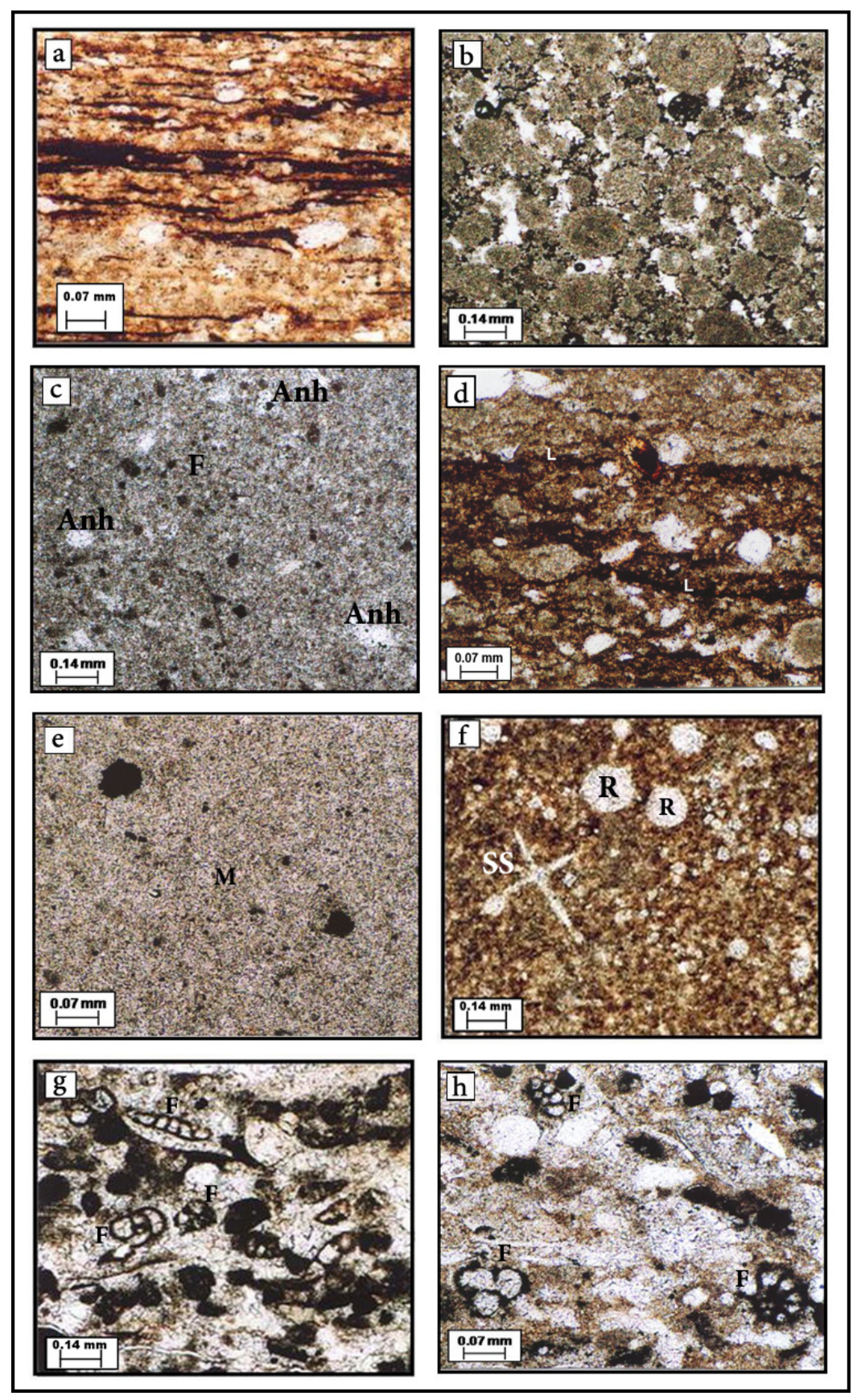

Plate 1. (a-h) Photographs of cores and thin sections (transmitted light) of the Makhul Formation from north and south fields in Kuwait:

(a) Grey to black laminated lime mudstone with high organic matter contents in Makhul Formation, (MU/18, 4010.3 m- Mutriba field).

(b) Massive carbonate (packstone and grainstone) in Makhul Formation, (RA/10, $3753 \mathrm{~m}$ Raudhatain field).

(c) Light grey, massive fine-grained mudstone (F) mixed with anhydrite (Anh) in the deepest part of Makhul Formation, (MN/2, $3267.9 \mathrm{~m}$ - Minagish field).

(d) Dark grey to black, fine-grained, highly bituminous laminated limestone (L) in the middle part of Makhul Formation, (MU/72, 4010.3 m- Mutriba field). 
(e) Light grey, massive fine-grained limestone in the shallowest part of Makhul Formation, (BG/18, $2635.9 \mathrm{~m}$ - Burgan field).

(f) Sponge spicules (SS) and radiolaria (R) associated in the laminated parts of Makhul Formation, (RA/1,3810.3 m - Raudhatain field).

(g) Dark grey grainstone carbonate showing the dominant benthic foraminiferas (F) in Makhul Formation, (MU/28, 4087.2 m - Mutriba field).

(h) Pyritiezed foraminiferas (F) in the laminated carbonate parts of Makhul Formation, (RQ/16, $4380.1 \mathrm{~m}$ - Ritqa field).

\subsubsection{Kerogen Elemental Analysis}

The kerogen elemental analysis for 11 samples in the Mutriba oilfield was examined by a LECO analyzer. The results show that the shallowest sample at depth $3998.5 \mathrm{~m}$ (sample no. 1) in Figure 2c, have high $\mathrm{H} / \mathrm{C}(1.01)$ and $\mathrm{O} / \mathrm{C}(0.05)$ atomic ratios, while these values decrease by increasing depth to reach $\mathrm{H} / \mathrm{C}(0.86)$ and $\mathrm{O} / \mathrm{C}(0.06)$ atomic ratios in samples no 10 and 11 at depths $4149.7 \mathrm{~m}$ and $4156.4 \mathrm{~m}$ respectively. The decrease in $\mathrm{H} / \mathrm{C}$ and $\mathrm{O} / \mathrm{C}$ ratios from the shallowest to the deepest parts of the formation show that samples 10 and 11 are in the peak oil generation zone in Makhul Formation at the northern oilfields (Figure 2c).

\subsubsection{Organic Geochemistry of the Oil Extracts}

Solvent extracts of four samples from the Mutriba Field show relatively high extract volume ranging from $1582 \mathrm{ppm}$ (sample MU-44) to $16387 \mathrm{ppm}$ (sample MU-48) (Table 5). Gas chromatograms of the extracts from these samples show a broad alkane distribution pattern up to $\mathrm{n}-\mathrm{C}_{41}$, with alkanes below $\mathrm{C}_{17}$ being either absent or strongly depleted (Figures $3 \mathrm{a}, \mathrm{b}, \mathrm{c}$, and d), Phytane is abundant, and the $\mathrm{Pr} / \mathrm{Ph}$ ratio is $0.29-0.52$ (Table 5). The isotope results show negative ranges of $\delta^{13}$ Csaturates $(-27.3$ to -27.8$), \delta^{13}$ CAromatics (-26.4 to -26.9$)$, and $\delta^{13}$ Cextracts (-26.6 to -27.5$)$ (Table 5). The saturate and aromatic isotopes ratios (Figures 3 a, $\mathrm{b}, \mathrm{c}$, and d) and the plot of $\delta^{13} \mathrm{C}$ saturate versus $\delta^{13} \mathrm{C}$ aromatics of Makhul bitumen fall in the "non-waxy marine" field (Figure 3d). 


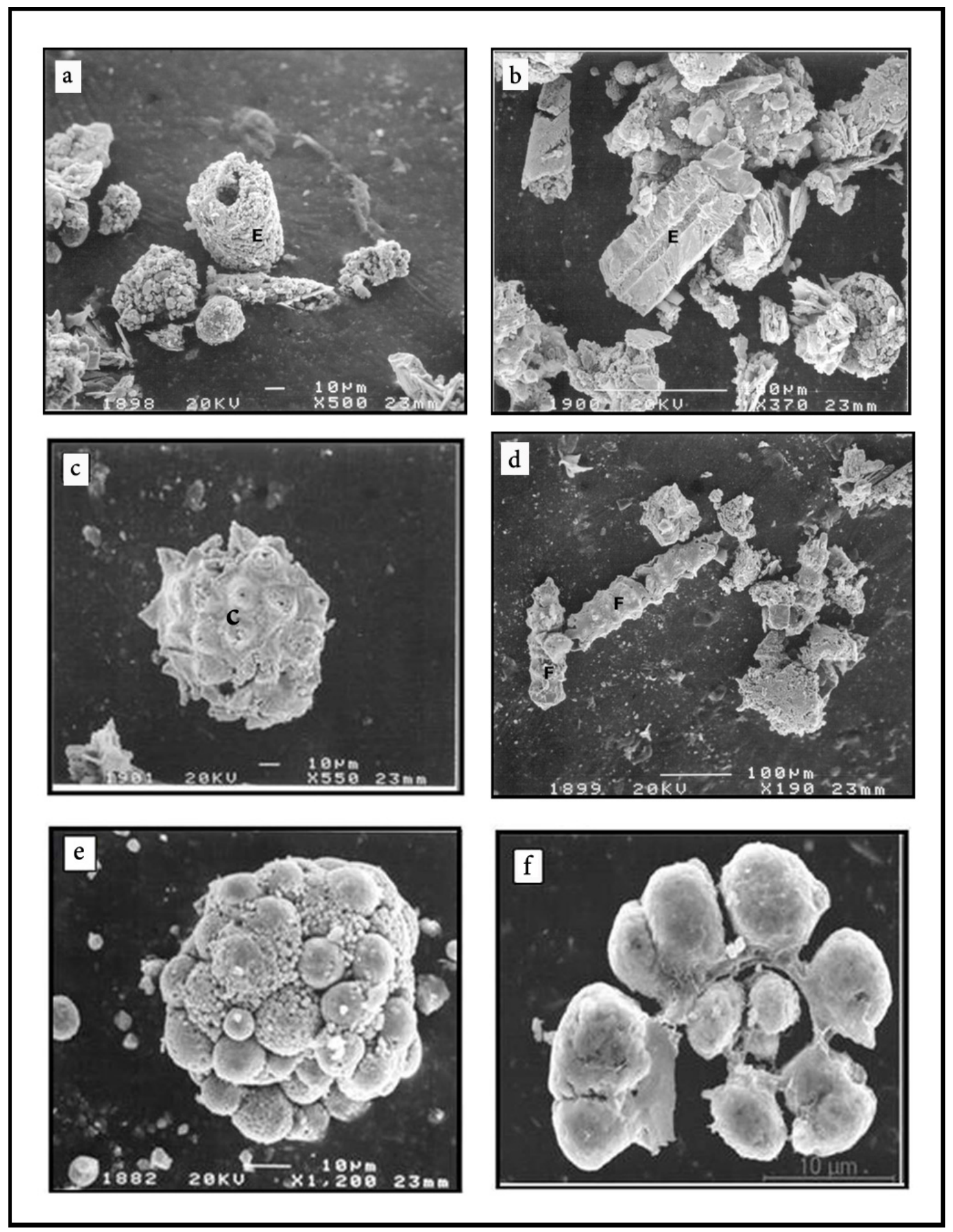

Plate 2. (a-f) Photomicrographs of the sample (MU/81, 4002.1m) from Makhul Formation in Mutriba field, north Kuwait taken by Scanning Electron Microscope (SEM):

(a) Cross-cut fragment of pyritized echinoid (E).

(b) Elongated fragment of pyritized echinoid (E).

(c) Pyritized coccolith (C).

(d) Foraminifera particles completely replaced by pyrite crystals (F).

(e) Framboidal pyrite crystals with cubic euhedral and subhedral crystals.

(f) Foraminifera particle pyritized and coated by a film of organic matter. 

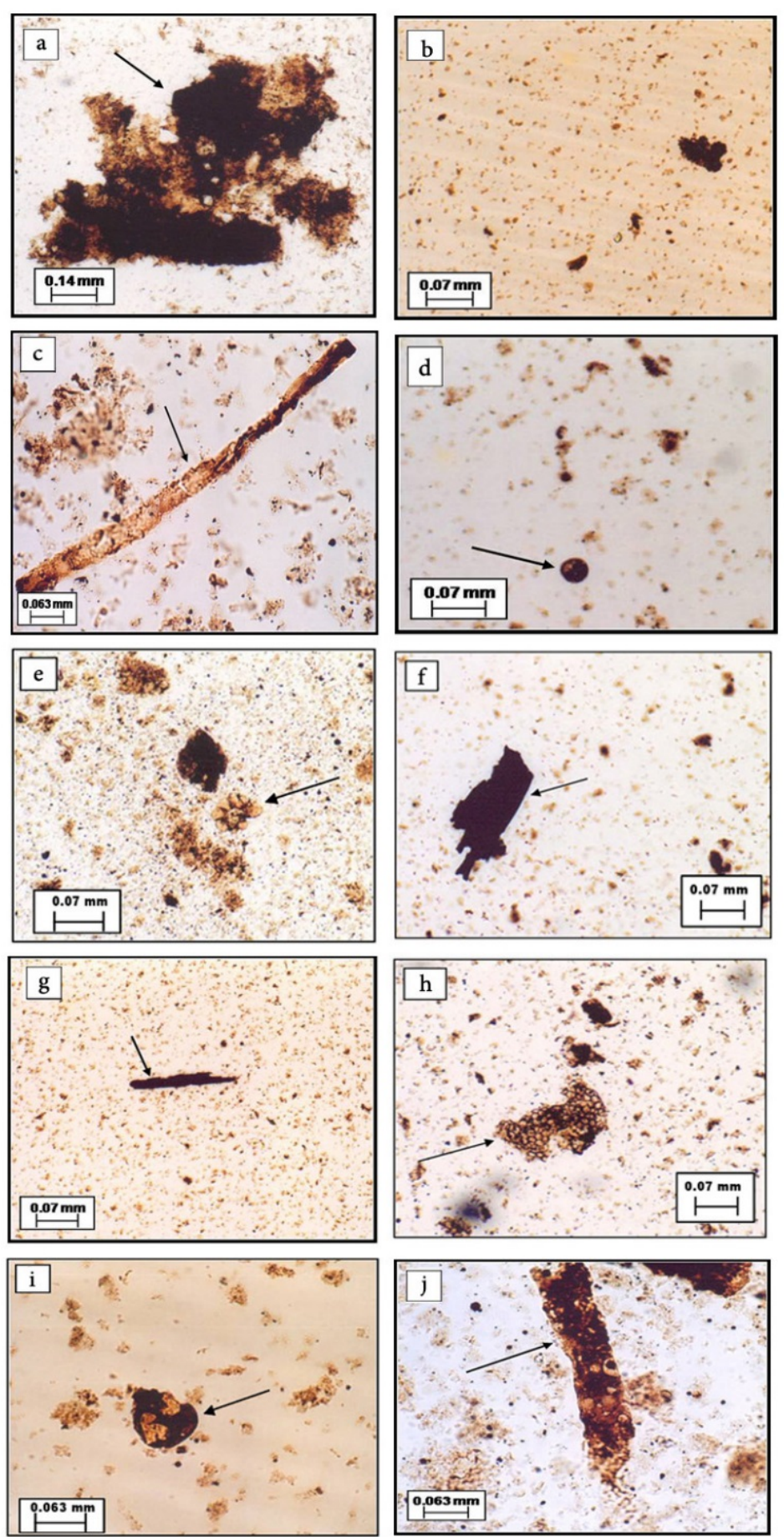

Plate 3. (a-j) Photomicrographs (transmitted light) of organic matter samples at different depths of the Makhul Formation in Mutriba field, north Kuwait:

(a) Large to moderate-size amorphous marine organic matter particles in the laminated intervals (MU/18, 4098.7m).

(b) Fine-size amorphous marine organic matter particles at the deepest part (MU/10, 4156.4m).

(c) Well preserved filamentous algae organic matter in the middle part (MU/36, 4078.3m).

(d) Well preserved marine spore organic matter at the middle part (MU/30, 4085.7m). 
(e) Well preserved foraminifera organic matter (MU/18, 4098.7m).

(f) Terrigenous organic matter at the shallowest part (MU/81, 4002.1m).

(g) Terrigenous organic matter at the deepest part (MU/16, 4149.7m).

(h) Well preserved plant tissues organic matter at the middle part (MU/56, 4057m).

(i) Biodegraded pollen grain at the deepest part (MU/10, 4156.4m).

(j) Biodegraded filamentous algae at the deepest part (MU/18, 4098.7m).

Table 4. The total organic carbon (TOC) of Makhul Formation core samples in Mutriba field (MU) was examined by LECO, north Kuwait (37 samples). Sample ID; depth in meter; TOC \% wt; Optical organic matter description; Type of structured organic matter; and kerogen colour.

\begin{tabular}{|c|c|c|c|c|c|}
\hline $\begin{array}{l}\text { Sample } \\
\text { ID }\end{array}$ & $\begin{array}{l}\text { Depth } \\
\text { (m) }\end{array}$ & $\begin{array}{l}\text { TOC } \\
\% \text { wt. }\end{array}$ & $\begin{array}{l}\text { Optical Organic Matter } \\
\text { Description }\end{array}$ & $\begin{array}{l}\text { Type of Structured Organic } \\
\text { Matter } \\
\end{array}$ & $\begin{array}{l}\text { Kerogen } \\
\text { colour }\end{array}$ \\
\hline $\mathrm{MU} / 84$ & 3998.5 & 0.42 & \multirow{2}{*}{$\begin{array}{c}\text { Moderate to fine OM } \\
\text { associated with some humic } \\
\text { angular lignin particles } \\
\end{array}$} & \multirow{2}{*}{$\begin{array}{l}\text { Biodegraded foraminiferal lining, } \\
\text { spores, and terrigenous }\end{array}$} & \multirow[b]{2}{*}{ Brown } \\
\hline $\mathrm{MU} / 81$ & 4002.1 & 0.88 & & & \\
\hline $\mathrm{MU} / 78$ & 4003.9 & 1.78 & \multirow{9}{*}{$\begin{array}{l}\text { Moderate OM associated } \\
\text { with structured particles }\end{array}$} & \multirow{9}{*}{$\begin{array}{l}\text { Well preserved foraminiferal linings } \\
\text { and spores }\end{array}$} & \multirow{9}{*}{$\begin{array}{l}\text { Light } \\
\text { brown }\end{array}$} \\
\hline $\mathrm{MU} / 75$ & 4007.6 & 1.36 & & & \\
\hline $\mathrm{MU} / 72$ & 4010.3 & 1.44 & & & \\
\hline $\mathrm{MU} / 71$ & 4011.2 & 2.02 & & & \\
\hline MU/ 69 & 4013.7 & 1.04 & & & \\
\hline MU/ 67 & 4016.7 & 1.54 & & & \\
\hline $\mathrm{MU} / 64$ & 4020.4 & 1.42 & & & \\
\hline $\mathrm{MU} / 62$ & 4022.8 & 1.37 & & & \\
\hline $\mathrm{MU} / 60$ & 4025.3 & 0.21 & & & \\
\hline $\mathrm{MU} / 58$ & 4027.7 & 0.45 & \multirow{7}{*}{$\begin{array}{l}\text { Fine to moderate OM with } \\
\text { structured particles associated } \\
\text { with few humic lignins }\end{array}$} & \multirow{7}{*}{$\begin{array}{l}\text { Well preserved spores, filamentous } \\
\text { algae, cuticle parts (tissues), pollen and } \\
\text { foraminiferal linings, few humic }\end{array}$} & \multirow{7}{*}{ Brown } \\
\hline $\mathrm{MU} / 56$ & 4057 & 1.82 & & & \\
\hline $\mathrm{MU} / 54$ & 4057.9 & 2.33 & & & \\
\hline $\mathrm{MU} / 52$ & 4059 & 2.64 & & & \\
\hline $\mathrm{MU} / 50$ & 4061.2 & 2.49 & & & \\
\hline $\mathrm{MU} / 48$ & 4063.7 & 3.4 & & & \\
\hline $\mathrm{MU} / 47$ & 4064.9 & 2.79 & & & \\
\hline $\mathrm{MU} / 46$ & 4066 & 4.13 & \multirow{14}{*}{$\begin{array}{c}\text { Moderate to coarse OM } \\
\text { associated with well preserved } \\
\text { structured particles and few } \\
\text { humic lignins }\end{array}$} & \multirow{14}{*}{$\begin{array}{l}\text { Irregular well preserved sharp edges } \\
\text { structured particles of unknown origin } \\
\text { spores, large numbers of pollen grains, } \\
\text { reddish colour foraminiferal linings, and } \\
\text { filamentous algae, marine pollen, spores, } \\
\text { and irregular resin particles associated } \\
\text { with few humic }\end{array}$} & \multirow{14}{*}{$\begin{array}{l}\text { Yellow } \\
\text { to light brown }\end{array}$} \\
\hline $\mathrm{MU} / 44$ & 4068.5 & 3.12 & & & \\
\hline $\mathrm{MU} / 42$ & 4071 & 1.84 & & & \\
\hline $\mathrm{MU} / 40$ & 4073.4 & 1.12 & & & \\
\hline $\mathrm{MU} / 38$ & 4075.9 & 1.33 & & & \\
\hline $\mathrm{MU} / 36$ & 4078.3 & 0.24 & & & \\
\hline $\mathrm{MU} / 34$ & 4080.7 & 1.02 & & & \\
\hline $\mathrm{MU} / 32$ & 4083.2 & 0.92 & & & \\
\hline $\mathrm{MU} / 30$ & 4085.7 & 1.26 & & & \\
\hline $\mathrm{MU} / 28$ & 4087.2 & 2.61 & & & \\
\hline $\mathrm{MU} / 26$ & 4089.3 & 1.28 & & & \\
\hline $\mathrm{MU} / 23$ & 4092.9 & 1.74 & & & \\
\hline $\mathrm{MU} / 21$ & 4095.4 & 2.25 & & & \\
\hline $\mathrm{MU} / 18$ & 4098.7 & 4.85 & & & \\
\hline $\mathrm{MU} / 16$ & 4149.7 & 0.29 & \multirow{4}{*}{$\begin{array}{l}\text { Fine OM with few } \\
\text { structured particles }\end{array}$} & \multirow{4}{*}{$\begin{array}{l}\text { few biodegraded pollen grains, } \\
\text { spores, foraminiferal linings, and } \\
\text { terrigenous }\end{array}$} & \multirow{4}{*}{ Brown } \\
\hline $\mathrm{MU} / 14$ & 4152.1 & 1.1 & & & \\
\hline $\mathrm{MU} / 12$ & 4154.5 & 1.07 & & & \\
\hline $\mathrm{MU} / 11$ & 4155.2 & 0.74 & & & \\
\hline $\mathrm{MU} / 10$ & 4156.4 & 1.47 & $\begin{array}{l}\text { Very fine OM with very } \\
\text { few structured particles }\end{array}$ & $\begin{array}{l}\text { Very few biodegraded pollen grains, } \\
\text { spores, foraminiferal linings, and } \\
\text { terrigenous }\end{array}$ & $\begin{array}{l}\text { Dark } \\
\text { brown }\end{array}$ \\
\hline
\end{tabular}




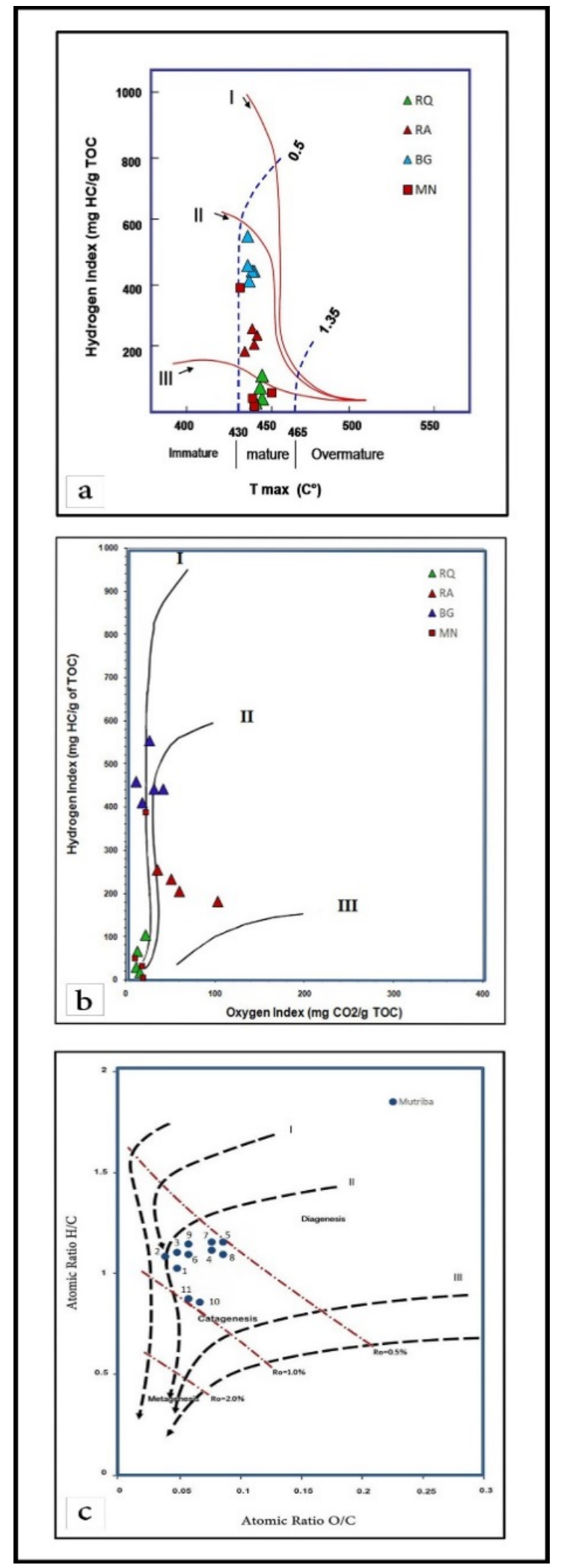

Fig. 2. (a) The hydrogen Index (HI) versus Tmax diagram of Makhul Formation showing kerogen type III mature in Ritqa (RQ), type II-III mature in Raudhatain (RA) northern oilfields, and type II-I mature in Burgan (BG), type III mature in Minagish (MN) southern oilfields in Kuwait. (b) The hydrogen index (HI) versus oxygen Index (OI) diagram of Makhul Formation showing kerogen type III in Ritqa (RQ), type II-III in Raudhatain (RA) northern oilfields, and 
type II-I in Burgan (BG), type III in Minagish (MN) southern oilfields in Kuwait. (c) Van Krevelen diagram for the Makhul Formation from Mutriba field. Cross-plot of $\mathrm{O} / \mathrm{C}=$ oxygen / carbon atomic ratio versus $\mathrm{H} / \mathrm{C}=$ hydrogen /carbon atomic ratio on $\mathrm{Ro} \%=$ vitrinite reflectance. 1 sample was selected along with the core due to changes in lithology and facies, organic matter size, total organic carbon content. Samples are numbered 1 to 11 according to depth, sample 1 is the shallowest, and sample 11 is the deepest. The kerogen is type II, and samples 10 and 11 are in the peak oil generation zone. Sample $1=\mathrm{MU} / 84(3998.5 \mathrm{~m}, \mathrm{Ro} \%=0.88) ; 2=\mathrm{MU} /$ 81(4002.1m, Ro\%=0.88); 3= MU/ 71(4011.2 m, Ro\%=0.75); 4= MU/ 58(4027.7 m, Ro\%=0.63); 5= MU/ 56 (4057 m, Ro\%=0.5); 6= MU/ 46 (4066 m, Ro\%=0.75); 7= MU/ 36 (4078.3 m, Ro\%=0.63); 8= MU/ 30 (4085.7 m, Ro\%=0.63); 9= MU/ 18 (4098.7 m, Ro\%=0.68); $10=\mathrm{MU} / 16$ (4149.7 m, Ro\%=0.94); and 11= MU/ 10 (4156.4 m, Ro\%=1.0) (All the Ro\% are assessment values from this Van Krevelan diagram).

Table 5. Geochemical results of bitumen extraction - Mutriba Field. TOC $\%=\%$ Total Organic Carbon; Extr.=Bitumen Extracts (ppm); $\mathrm{CV}=$ Canonical value; $\mathrm{Pr}=\mathrm{Pristane} ; \mathrm{Ph}=\mathrm{Phytane} ; \mathrm{n}-$ c17=n-heptadecane; n-c18=n-octadecane; $\delta 13 \mathrm{C} \mathrm{Sat}=$ saturates $; \delta 13 \mathrm{CAr}=$ Aromatics $; \delta 13 \mathrm{C}$ $\mathrm{Ext}=$ extracts; Homopopane $=\mathrm{C} 32 \mathrm{~S} /(\mathrm{S}+\mathrm{R}) ; \mathrm{C} 29$ aaa $\mathrm{St}=\mathrm{S} /(\mathrm{S}+\mathrm{R}) ; \mathrm{C} 29 \mathrm{St}=(\mathrm{bbS}+\mathrm{aaR})$; Norh/Hop = Norhopane/Hopane; Dister/aaaSter $(\mathrm{C} 27)=\mathrm{Ts} /(\mathrm{Ts}+\mathrm{Tm}) \mathrm{C} 27$; Homohopanes $=$ C24/C23 tricyclic; Terpanes $=$ C22/C21 tricyclic

\begin{tabular}{|c|c|c|c|c|c|c|c|c|c|c|c|c|c|c|c|}
\hline \multirow{2}{*}{$\begin{array}{r}\text { Sa } \\
\text { mple ID }\end{array}$} & \multirow{2}{*}{$\begin{array}{r}\text { De } \\
\text { pth (m) }\end{array}$} & \multirow{2}{*}{\multicolumn{2}{|c|}{$\begin{array}{l}\text { TOC\% } \\
\text { by LECO }\end{array}$}} & \multirow{2}{*}{$\begin{array}{r}\text { Ext } \\
\text { r. }(\mathrm{ppm})\end{array}$} & \multirow{2}{*}{$v^{c}$} & \multicolumn{5}{|c|}{ GC-MS Data } & \multicolumn{5}{|c|}{ Isotopic Data } \\
\hline & & & & & & 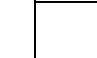 & $\mathbf{P r} / \mathbf{P h}$ & $\begin{array}{l}\text { Pr/n- } \\
\mathrm{C} 17\end{array}$ & & $\begin{array}{l}\mathrm{Ph} / \mathrm{n}- \\
18\end{array}$ & & C Sat & $\delta^{13} \mathrm{CAr}$ & & $\delta^{13} \mathrm{C}$ Ext \\
\hline $\begin{array}{l}\text { MU } \\
-56\end{array}$ & $\begin{array}{l}{ }^{4} 40 \\
57^{4}\end{array}$ & \multicolumn{2}{|c|}{1.82} & $8^{236}$ & $2.24^{-}$ & & 0.39 & 0.28 & \multicolumn{2}{|r|}{0.52} & \multicolumn{2}{|c|}{-27.6} & -26.5 & \multicolumn{2}{|r|}{-27.1} \\
\hline $\begin{array}{l}{ }^{M U} \\
-52\end{array}$ & $5^{40}$ & \multicolumn{2}{|c|}{2.64} & $4^{682}$ & \multicolumn{2}{|c|}{$2.52^{-}$} & 0.23 & 0.26 & \multicolumn{2}{|r|}{0.5} & \multicolumn{2}{|c|}{-27.4} & -26.4 & \multicolumn{2}{|r|}{-27.1} \\
\hline $\begin{array}{l}\text { MU } \\
-48\end{array}$ & $\begin{array}{r}40 \\
63.7\end{array}$ & \multicolumn{2}{|c|}{3.4} & $\begin{array}{l}163 \\
87^{163}\end{array}$ & \multicolumn{2}{|c|}{$3.23^{-}$} & 0.29 & 0.33 & \multicolumn{2}{|r|}{0.62} & \multicolumn{2}{|c|}{-27.3} & -26.6 & \multicolumn{2}{|r|}{-26.6} \\
\hline $\begin{array}{l}\text { MU } \\
-44\end{array}$ & $\begin{array}{r}40 \\
68.5\end{array}$ & \multicolumn{2}{|c|}{3.12} & $2^{158}$ & \multicolumn{2}{|c|}{$2.65^{-}$} & 0.52 & 0.29 & \multicolumn{2}{|r|}{0.42} & \multicolumn{2}{|c|}{-27.8} & -26.9 & \multicolumn{2}{|r|}{-27.5} \\
\hline \multirow[b]{2}{*}{$\begin{array}{r}\text { Sa } \\
\text { mple ID }\end{array}$} & \multicolumn{15}{|c|}{ Aromatic Biomarkers (ARB) } \\
\hline & ${ }_{\text {PI1 }}^{{ }^{\text {M }}}$ & $\begin{array}{c}\mathrm{m}^{\mathrm{R}} \\
(\mathrm{Ro} \%) \\
\end{array}$ & \multicolumn{2}{|c|}{$\begin{array}{c}\text { DBT/Phe } \\
\text { nanthrene }\end{array}$} & \multicolumn{2}{|c|}{$\begin{array}{l}\text { \% } 27 \\
\text { MAS }\end{array}$} & $\begin{array}{l}\quad \% 28 \\
\text { MAS }\end{array}$ & MA & 29 & $\begin{array}{r}\mathbf{T} \\
\mathbf{A S}+\mathbf{7}\end{array}$ & $\begin{array}{l}\text { AS/(M } \\
\text { TAS }\end{array}$ & & $\begin{array}{l}\text { C21+C22)MA } \\
\text { otal MAS }\end{array}$ & $\begin{array}{r}\text { (C2 } \\
\text { S/ Tot }\end{array}$ & $\begin{array}{l}0+\text { C21)TA } \\
\text { tal TAS }\end{array}$ \\
\hline $\begin{array}{l}\text { MU } \\
-56\end{array}$ & & $62^{0 .}$ & & 0.2 & & 33.4 & 26.4 & & 0.2 & & 0.85 & & 0.13 & & 0.14 \\
\hline $\begin{array}{l}\text { MU } \\
-52\end{array}$ & $38^{0 .}$ & & & 0.36 & & 29.9 & 27.5 & & 2.5 & & 0.77 & & 0.09 & & 0.15 \\
\hline $\begin{array}{l}\text { MU } \\
-48\end{array}$ & $39^{0 .}$ & ${ }_{61}^{0 .}$ & & 0.39 & & 29.9 & 28.1 & & 2 & & 0.74 & & 0.09 & & 0.17 \\
\hline $\begin{array}{l}\text { MU } \\
-44\end{array}$ & $43^{0 .}$ & $63^{0 .}$ & & 0.04 & & 27.4 & 35.6 & & 7 & & 0.89 & & 0.11 & & 0.12 \\
\hline & & & & & & & Satur & ate Biomar & Kers (SB & & & & & & \\
\hline $\begin{array}{r}\text { Sa } \\
\text { mple ID }\end{array}$ & $\begin{array}{r}H \\
\text { omopop } \\
\text { ane }\end{array}$ & $\begin{array}{r}\quad \mathrm{C} \\
29 \\
\text { aaa St }\end{array}$ & ${ }_{29 \mathrm{St}}^{\mathrm{C}}$ & $\begin{array}{l}\text { orh/ } \\
\text { Hop }\end{array}$ & $\begin{array}{c}\text { D } \\
\text { ister/a } \\
\text { aaSte } \\
\mathbf{r} \\
(\mathrm{C} 27)\end{array}$ & $\begin{array}{r}H \\
\text { opanes } \\
(H 35 / H \\
34)\end{array}$ & $\begin{array}{r}\text { Ho } \\
\text { mohopa } \\
\text { nes }\end{array}$ & $\underset{\text { es }}{\text { erpan }}$ & $\begin{array}{c}\mathrm{C} 27 \\
\text { aaa } \\
\mathbf{R}\end{array}$ & $\begin{array}{c}\mathrm{C} 28 \\
\text { aaa } \\
\mathrm{R}\end{array}$ & $\begin{array}{c}\mathrm{C} 27 \\
\mathrm{abb} \\
\mathrm{S}\end{array}$ & $\begin{array}{c}\mathrm{C} 28 \\
\mathrm{abb} \\
\mathrm{S}\end{array}$ & $\begin{array}{c}\% \\
\text { C29 abb S } \\
\text { C26/ } \\
\text { C25 } \\
\text { Tricyclic }\end{array}$ & $\begin{array}{r}\text { Te } \\
\text { rppanes }\end{array}$ & $\begin{array}{c}\text { St } \\
\text { eranes } \\
\text { /Hopan } \\
\text { es }\end{array}$ \\
\hline $\begin{array}{l}\text { MU } \\
-56\end{array}$ & 58 & $.42^{0}$ & $.52^{0}$ & .710 & .5 & 54 & $3^{1.0}$ & $.83^{0}$ & $6.4^{3}$ & $6.9^{1}$ & $2.3^{3}$ & $3.9^{2}$ & 43.9 & $76^{0 .}$ & 21 \\
\hline $\begin{array}{l}\text { MU } \\
-52\end{array}$ & $58^{0 .}$ & $.39^{0}$ & $.5^{0}$ & .710 & $.46^{0}$ & $56^{0 .}$ & $8^{1.0}$ & $.99^{0}$ & $4.9^{3}$ & $6.9^{1}$ & $1.4^{3}$ & $4.5^{2}$ & 44.2 & $95^{0 .}$ & 19 \\
\hline $\begin{array}{l}\text { MU } \\
-48\end{array}$ & $58^{0 .}$ & $.4^{0}$ & $.52^{0}$ & .79 & $.47^{0}$ & $56^{0 .}$ & $7^{1.0}$ & $.86^{0}$ & $4.2^{3}$ & $8.6^{1}$ & $2.2^{3}$ & $4.4^{2}$ & 43.4 & $74^{0 .}$ & $2^{0 .}$ \\
\hline $\begin{array}{l}\text { MU } \\
-44\end{array}$ & $58^{0 .}$ & $.43^{0}$ & $.51^{0}$ & .519 & $.26^{1}$ & $66^{0 .}$ & $8^{0.8}$ & $\begin{array}{l}{ }^{0} \\
.63^{2}\end{array}$ & $0.8^{3}$ & $0^{2}{ }^{2}$ & $1.5^{3}$ & $3.6^{2}$ & 44.7 & $89^{0 .}$ & $25^{0 .}$ \\
\hline
\end{tabular}




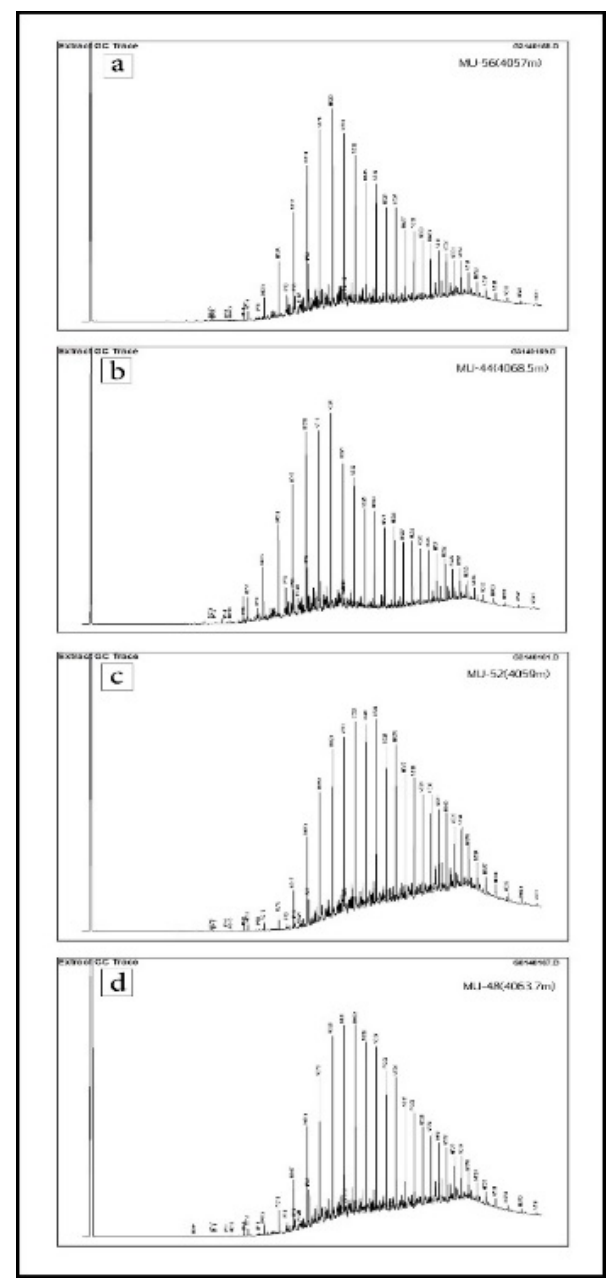

Fig. 3. (a) GC traces of Makhul Formation extracts of samples from Mutriba field in Kuwait (MU/56, 4057 m), (b) MU/44, 4068.5m, (c) MU/52, 4059m, (d) MU/48, 4063.5m.

\section{Discussion}

Makhul Formation is composed of dark grey to black laminated organic-rich marly carbonate mudstones with shale interbeds and high organic carbon contents. In the northern studied oilfield, the formation is dominated by thick laminated carbonate layers mixed with shale and marl while it is mostly massive carbonate in the southern oilfields. In Kuwait, the formation is at its maximum depths in the north (Ritqa oilfield) $(4500-4300 \mathrm{~m})$ and gradually decreasing until it reaches its shallowest depth in the south (Burgan oilfield) $(2700-2500 \mathrm{~m})$ (Figure 4). The shallowest section of the formation and near the lower contact of the upper Minagish Formation, the Makhul is composed of grey massive fine-grained carbonate facies. The variation in thickness between the north (335.3m thick) and the south (91.5m thick) reflects a possible deeper water level old basin at northwest Kuwait, deepening toward north-northwest to open marine anoxic condition environment relative to the south-southwest. The oxygen-rich condition in a more open-marine environment prevailed during the deposition time of the lower and upper parts of the formation (Figure 5).

The TOC content of the Makhul Formation is in general relatively high in north and south Kuwait. The organic matter is dominantly amorphous algal marine type. Low TOC intervals 
are found in the massive carbonate at the deepest and shallowest parts of the formation. While high TOC intervals are associated with the laminated carbonate found in the middle parts of the formation in both north (4.85\%wt. Mutriba oilfield) and south of the state $(6.7 \% \mathrm{wt}$. Minagish oilfield) (Tables 1 and 2).

Kerogen elemental analyses for rocks from the Mutriba field indicate predominant type II kerogen (Figure 2c). The Microscopic study of the kerogen shows a well preserved and relatively large to moderate-size amorphous algal marine type. It is predominantly concentrated and associated in the laminated intervals of the formation (Table 4 and Plate 3a). There are also well-preserved structured zoo- and phytoplankton of marine origin, (Plate $3 \mathrm{c}, \mathrm{d}, \mathrm{g}$, and $\mathrm{j}$ ) filamentous algae, sponge spicules, foraminifera. They reflect deep marine anoxic conditions associated causing the deposition of fine-grained and laminated carbonate. It is more abundant in the northwest of Kuwait (335.3 $\mathrm{m}$ in thickness) compared to the south. Some of these organic matter particles are pyritized reflecting an anoxic depositional environment.

The shallowest massive carbonate section contains rare concentrations of terrigenous spores, pollen, resins, few woody particles, and some plant tissues are mixed with poorly preserved, dark brown colour organic matter (Table 4 and Plate $3 \mathrm{e}, \mathrm{f}, \mathrm{h}, \mathrm{i}$ and $\mathrm{j}$ ). These might be related to minor input of terrigenous organic matter during infrequent episodes of siliciclastic. The kerogen type on Tmax vs HI plot (Figure $2 b$ ) for the other oilfield samples show slight variation between the kerogen types. In Burgan, the kerogen is type II while it is typed II-III and III in both Raudhatian and Ritqa fields.

The result of the extract of four samples from the Makhul Formation shows that it is derived from a marine carbonate source rock (Figures 6a and b, c) (Hughes et al., 1995). The narrow range of carbon 13 isotope results $(-27.3 \%$ to $-27.8 \%$, and 0.23 to 0.59$)$ fall in the "Mesozoic Carbonates" area (Figures $6 \mathrm{~b}$ and $6 \mathrm{~d})$. The pristane/phytane $(\mathrm{Pr} / \mathrm{Ph})$ ratio versus the Canonical Value or CV (Sofer, 1984; Moldowan et al., 1985; Sofer et al., 1986) shows CV values $<0.47$ indicates a predominance of marine input. Makhul Formation extracts show negative Canonical Value CVs (-2.24 to -3.23) and are concordant with $\mathrm{Pr} / \mathrm{Ph}$ ratios of 0.23 to 0.52 , and plot in the marine organic matter region (Table 5, Figures 6e and f). A slight variation and homogeneity in source rock type are clearly shown by the distribution patterns of $\alpha \alpha \alpha$ (20R) and $\alpha \beta \beta$ (the 20S) C27 and C29 steranes in the four Mutriba field extracts (Table 5, Figures 6g and h). And similar MAS abundances in the ternary plot of C27 - C29 monoaromatic steranes (MAS) (Figure 6i).

The Van Krevelen diagram shows that in Mutriba oilfield $(\mathrm{Mu} / 10,4156.4 \mathrm{~m}$ and MU/16, $4149.7 \mathrm{~m}$ ) the formation reached almost late stages of catagenesis maturity level which is equivalent to $\mathrm{Ro} \%=1.0$, at its deepest part of the formation. The kerogens show brown colour under the microscope reflecting maturity too. Tmax $423-446 \mathrm{C}^{\circ}$ and the production index (PI) $(0-0.41)$ (Figure 4) in the other four oilfields reflect mature source rocks. High Tmax values indicate peak oil generation stage in some of the samples such as in north oilfields, $(\mathrm{RQ} / 18$, $4378.6 \mathrm{~m})$ and $(\mathrm{RQ} / 9,4387.5 \mathrm{~m})$ reach $440{ }^{\circ} \mathrm{C},(\mathrm{RA} / 4,3806.4 \mathrm{~m})$ reaches $437{ }^{\circ} \mathrm{C}$, and in south oilfields, $(\mathrm{MN} / 3,3104.5 \mathrm{~m})$ reaches $446{ }^{\circ} \mathrm{C}$ (Table 2 ). 


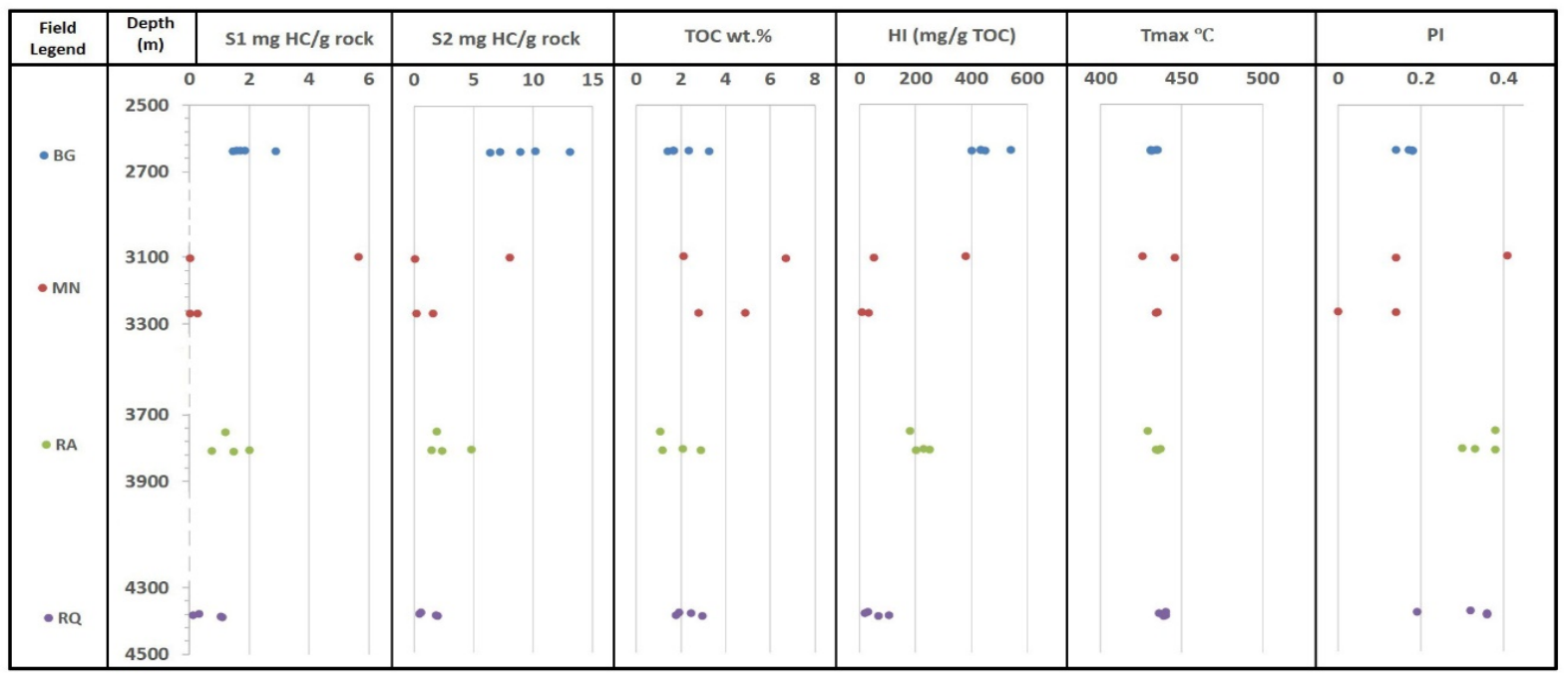

Fig. 4. Geochemical logs of Makhul Formation source rock samples from Ritqa (RQ), Raudhatain (RA), Burgan (BG), and Minagish (MN) in the north and south Kuwait showing the depths (m) versus S1, S2, TOC wt\%, HI, PI and Tmax by RE6.

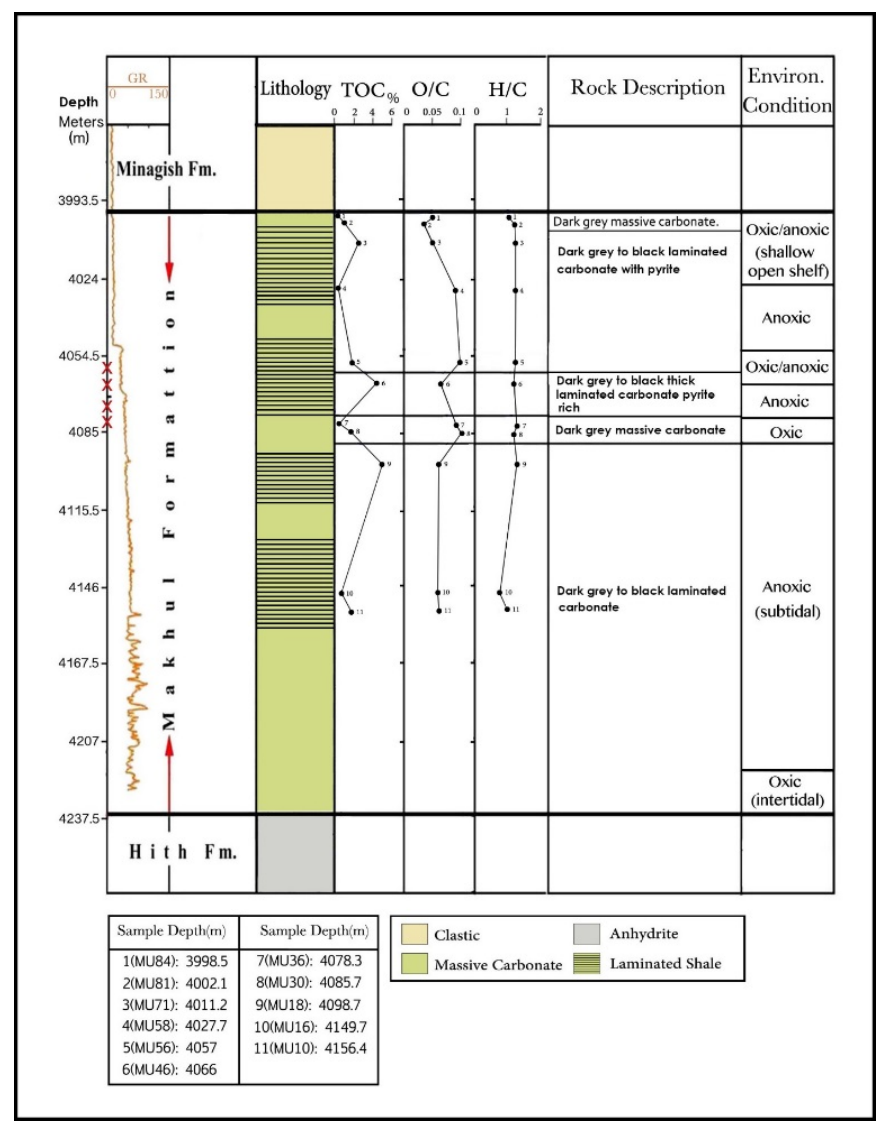

Fig. 5. Lithostratigraphic section of the Makhul Formation at Mutriba field, Kuwait, showing the Gamma Ray log, Depth (m), Lithology, Sedimentary facies, TOC= total organic carbon, $\mathrm{H} / \mathrm{C}=$ hydrogen /carbon atomic ratio, $\mathrm{O} / \mathrm{C}=$ oxygen/carbon atomic ratio, Rock description, and Environmental condition. $(\mathrm{x})$ sign on the depth axis is showing the four samples used for the organic geochemical studies. 


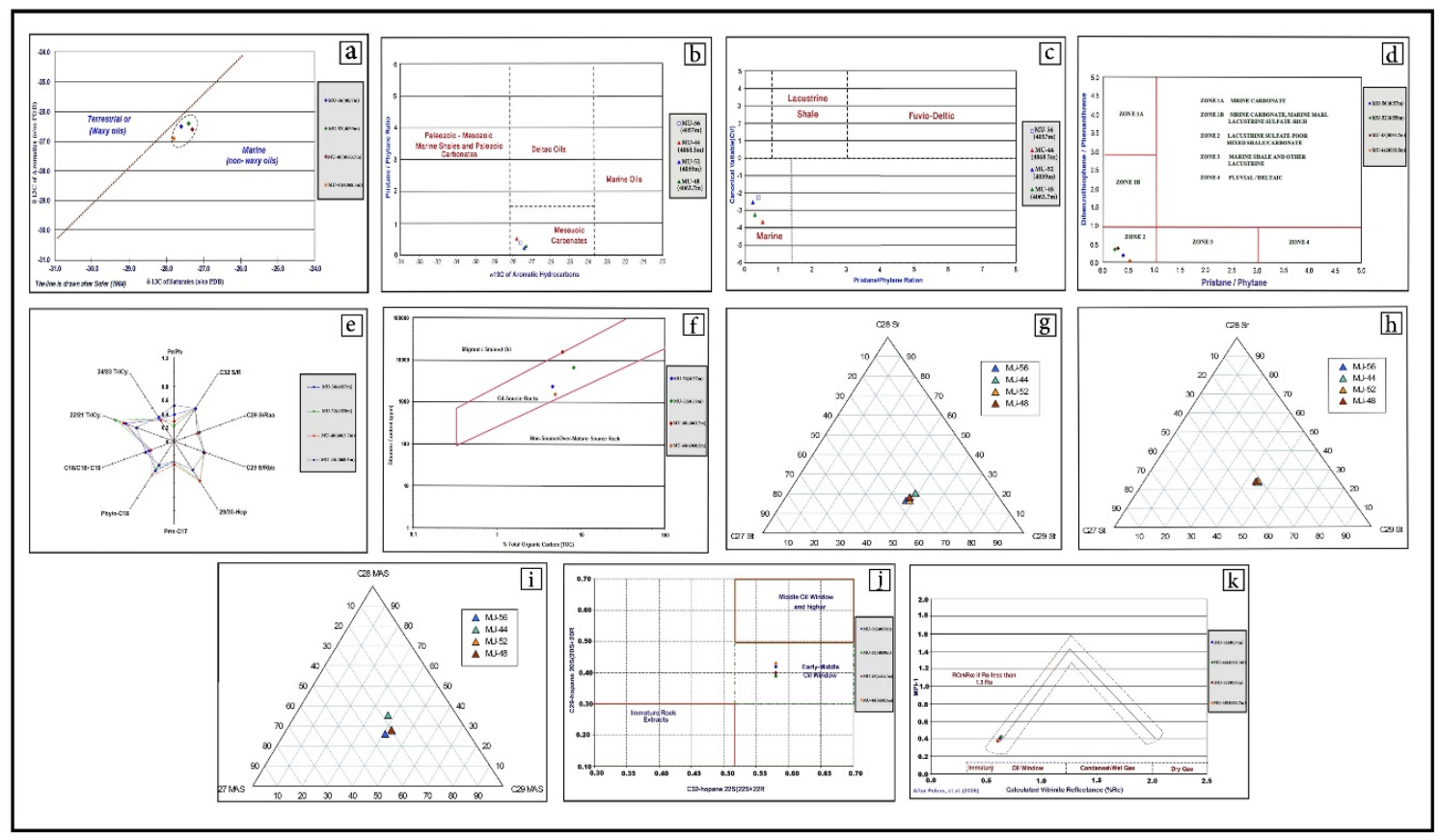

Fig. 6 (a) Cross plot of $\delta^{13} \mathrm{C}$ saturates versus $\delta^{13} \mathrm{C}$ aromatics for extracts of the Makhul Formation samples from Mutriba field (plot after Sofer, 1984), (b) Cross plot of pristane/phytane ratio versus $\delta^{13} \mathrm{C}$ ratio of aromatic fraction suggests genetic relationship among the Makhul bitumen studied and infer depositional environment (modified after Chung et al., 1992), (c) Cross plot of pristane/phytane versus canonical variable (CV) for Makhul bitumen studied (modified from Peters, et al., 2005). CV 0.49 indicates mainly waxy terrigenous oil, while CV 0.49 indicates mainly non-waxy marine oil, (d) The inferred source rock lithofacies plot of DBT/Phen versus pristane/phytane ratio for the Makhul bitumen studied (after Hughes et al., 1995) indicates that bitumen analyzed fall in zone 2, (e) Star diagram plot (Kaufman et al., 1990) reveals a comparison between the rock bitumens studied for Makhul Formation extracts of samples from Mutriba field based on gas chromatography (pristane/phytane, pristane.n-C17, phytane/n-C18, and N-C18/n-C18+n-C19) and biomarker (GC-MS) parameters (22S/22R C32 hopanes, C29/C30 - hopanes, the 20S/20RC29 aaasteranes, 20S/20R C29 abbsteranes, C22/C21 tricyclic terpenes, and C24/C23 tricyclic terpanes). The insignificant differences observed on pristane/phytane, C29/C30-hopane, and C22/C21 tricyclic terpane ratios may be attributed to either maturity level or organic facies, or both, (f) Plot of TOC content versus bitumen content for four samples of the Makhul Formation from Mutriba field. Oil-prone rock samples have high bitumen, but bitumen/TOC ratios $>0.25$ indicate contamination. Migrated oil or drilling additive (modified after Tissot \& Welte,1984), (g) Ternary diagrams showing the relative abundances of $\mathrm{C}_{27}, \mathrm{C} 28$. and $\mathrm{C} 29$ regular steranes, the diagrams are used to infer genetic relationship among the bitumen studied $\{5 \mathrm{a}, 14 \mathrm{a}, 17 \mathrm{a}(\mathrm{H})$ $20 \mathrm{~S}+20 \mathrm{R}$, (h) $\{5 \mathrm{a}, 14 \mathrm{~b}, 17 \mathrm{~b}(\mathrm{H}) 20 \mathrm{~S}+20 \mathrm{R}\}$, (i) monoaromatic steranes in Makhul bitumen studied (Moldowan, et al., 1985), (j) Cross plot of (22s/22S+22R) C32-hopane versus (the 20S/20S+20R) C29-sterane as maturity indication for Makhul bitumen studied after (Seifert \& Moldowan, 1980). Samples showing (22S/22S+22R) ratios in the range of $0.50-0.54$ have barely entered the oil window, while ratios in 0.57-0.62 indicate that the main oil phase has 
been reached or surpassed, (k) Methylphenanthrene Index (MPI) is useful as vitrinite reflectance for maturity assessment (Radke \& Welte, 1983). It shows a cross plot of MPI versus calculated vitrinite reflectance for Makhul bitumen (modified after Peters, et al., 2005).

The analysed extracts of the Makhul Formation from Mutriba oilfield are showing maturity at a high level. The maturity parameters in the plot of $22 \mathrm{~S} /(22 \mathrm{~S}+22 \mathrm{R}) \mathrm{C} 32$ hopane ratio versus the $20 \mathrm{~S} /(20 \mathrm{~S}+20 \mathrm{R}) \mathrm{C} 29$ sterane ratio (Figure $6 \mathrm{j}$ ), which shows values of 0.58 and 0.39 to 0.47 , respectively, is typical of "mid-late oil window" maturity (Moldowan \& Peters, 1991). Previous studies have shown that samples showing $22 \mathrm{~S} /(22 \mathrm{~S}+22 \mathrm{R}) \mathrm{C} 32$ ratios in the range 0.50 to 0.54 have barely entered the oil generation window, while ratios of 0.55 to 0.62 correlate with the main oil window (Peters \& Moldowan, 1993) (Table 5). The moderate MPI-1 versus \% Rocalc. values $(0.38$ to 0.56$)$ in the cross plot of Figure $6 \mathrm{k}$ obtained for the Makhul bitumen suggest that they were generated within the "early-mid" oil window. Studies have demonstrated that aromatic hydrocarbon parameters based on phenanthrenes and thiophenes, such as the methylphenanthrene Index (MPI) are as good, as if not superior to, \%Ro calculated using methylphenanthrene values (Radke et al., 1982; Farrington et al., 1988). However, it should be noted that due to evaporative loss during extraction and concentration procedures, the MPI-1 and Ro\% values should be interpreted with caution.

Thus, the geochemical result of the extract indicates that the Makhul Formation is a marine mixed shale/carbonate source rock, deposited in a reducing environment rich in marine organic matter input of Mesozoic carbonate marine oil. Generally, it reached the oil window maturity level.

The result of the kerogen study with correlation with its rock type may show the oxygen level variation during the depositional time. At the start of Makhul Formation time, the sedimentation started by light grey massive carbonate rocks in a shallow-water low stand sea level (regression) and short period of oxic water column condition in an intertidal depositional environment (Figure 5) This section contains gypsum that could be due to the hydration of anhydrite (Tucker, 1981), and intermixed with the upper boundaries of the underlying Hith Formation anhydrite (Plate 1c). It contains low TOC and few quantities of very fine poorly dark brown colour biodegraded organic matter (Plate $3 b$ ), such as spores, pollen, resins, woody particles, and a few plant tissues of terrestrial origin (Plates $3 \mathrm{f}$, g, and h) (Table 4).

The sedimentation is followed by the middle section of the Makhul Formation, which is deposited by dark grey to black laminated carbonate, rich in quartz in the north part of Kuwait. This is related to the incorporation of the high association of sponge spicules, which are made of silica and chert. High Fe and S content, formed by pyrite minerals, is associated with the laminated intervals of the formation, which were likely produced by sulfate-reducing bacteria. These bacteria induce reactions whereby sulfides are produced in anoxic depositional conditions (Bjorlykke, 1989). Light brown moderate-coarse amorphous organic matter well preserved indicates a low oxygen level of deposition in the middle part. The organic matter was deposited in a reducing environment (carbonate facies) and deeper-water anoxia settings during the deposition condition (GC-MS data), typical non-biodegraded origin (Tissot \& Welte, 1984), and a high atomic ratio of $\mathrm{O} / \mathrm{C}$ in kerogen ranging from 0.06 to 0.09 (Table 1). Intrashelf basins were present in north Kuwait during the depositional time, as north Kuwait was part of the Lorestan intra-shelf basin (Murris, 1980; Sharland et al., 2001; Bahman, 2004). 
The sedimentation of the Makhul Formation ends with grey fine-grained massive carbonate, associated with fine brown colour amorphous biodegraded organic matter at its upper part (Table 4) with a high oxygen level of deposition (oxic) in a shallow open shelf environment.

The alterations of lamination intervals anoxic condition with massive carbonate, oxic condition rock intervals within Makhul Formation indicate that the depositional condition was changing alternatively in short cycles, which is equivalent to eustatic-cycle changes explained by Haq et al. (1988).

\section{Conclusions}

1. Makhul Formation (Lower Cretaceous-Early Berriasian) is dark grey to black laminated, bituminous, marly, micritic, and shaly limestone.

2. The Makhul Formation was deposited in various depositional conditions; shallow water intertidal to intertidal-subtidal, the open marine depositional environment in an intrashelf basin, with its deepest part in the north-northwest parts of Kuwait

3. Makhul Formation is one of the major Lower Cretaceous source rocks in Kuwait. It contains high organic matter content where the TOC ranges between $4.85 \%$ wt in the north and $6.7 \%$ wt in south Kuwait.

4. The organic matter of Makhul Formation shows kerogen type II with well-preserved organic-rich zone associated with the laminated rock structure in the deep oilfields in the north, and kerogen type II-III with well-preserved amorphous marine mixed with a minor concentration of structured marine and terrestrial organic matter in the shallow oilfields in south Kuwait.

5. The Makhul Formation is a mature source rock where the maturity level is in the early oil generation to peak oil generation stage in its deepest part in north Kuwait.

6. The lateral variation of depositional conditions in Kuwait resulted in different source rock quality between the northern and southern parts of the state.

7. Along Makhul Formation depositional time, the variation of depositional condition from oxic and anoxic seawater resulted in fluctuating like the organic matter and its preservation which was reflected in the type of source rock variation along with the formation thickness.

\section{ACKNOWLEDGMENTS}

The authors are grateful to The Ministry of Oil and the Kuwait Oil Company for providing samples and logs. Financial support was provided by the College of Graduate Studies at Kuwait University. We wish to thank our colleagues in the Electron Microscopy Unit (EMU) of Kuwait University for their help in obtaining the images. Thanks, are also extended to Mr. Sarfaraj Shelwan from the Department of Earth and Environmental Sciences for his help in analyzing samples in the petroleum geochemistry lab in the department. Thanks are extended to Weatherford Labs who performed the geochemical analyses of the rock extracts. 


\section{References.}

Abdullah, F., Carpentier, B., Kowalewski, I., \& Huc, A.Y. (2005). The organic geochemical approach in carbonate-clastic source-reservoir succession. Kuwait Journal of Science, 32(2):101-118.

Abdullah, F.H. \& Kinghorn, R.R.F. (1996). A preliminary evaluation of Lower and Middle Cretaceous source rocks in Kuwait. Journal of Petroleum Geology, 19 (4):461-480.

Abdullah, F.H., \& Connan, J. (2002). geochemical study of some Cretaceous rocks from Kuwait: comparison with oils from Cretaceous and Jurassic reservoirs. Organic Geochemistry, $33: 125-148$.

Abdullah, F.H.A., Nederlof, P.J.R., Ormerod, M.P. \& Kinghorn, R.R.F. (1997). Thermal history of Lower and Middle Cretaceous source rock in Kuwait. GeoArabia, 2(2):151-163.

Al-Ameri, T.K., Al-Musawi, F.S. \& Batten, D.J. (1999). Palynofacies indication of depositional environments and source potential for hydrocarbons: uppermost Jurassic-basal Cretaceous Sulaiy Formation, Southern Iraq. Cretaceous Research, 20:359-363.

Al-Fares, A., Bouman, M. \& Jeans, P. (1998). A new look at the Middle to Lower Cretaceous stratigraphy, Offshore Kuwait. GeoArabia, 3(4):543-560.

Al-Rifaiy, I.A. \& Lemone, D. (1987). Calpionellids and the Late Jurassic and Early Cretaceous stratigraphy of Kuwait and the Gulf Region. Marine Micropaleontology. 12:383-388.

Alsharhan, A.S. \& Nairn, A.E.M. (1997). Sedimentary basins and Petroleum Geology of the Middle East. Elsevier Science B.V., New York. Pp. 843.

Alsharhan, A.S., Strohmenger, C. J., Abdullah, F.H. \& Al Sahlan G. (2014). Mesozoic Stratigraphic Evolution and Hydrocarbon Habitats of Kuwait. Memoir 106: Petroleum Systems of the Tethyan Region, Pp. 541-611.

Arasu, R.T., Singh, S.K., Al-Adwani, T.F., Khan, B.Z., Macadan J. \& Abu-Ghaneej, A.F.N. (2012). Hydrocarbon prospectivity of the Late Jurassic - Early Cretaceous Makhul Formation in North and Northwestern Kuwait. Proceedings of the 4th EAGE Workshop on Arabian Plate Geology. Abu Dhabi, United Arab Emirates.

Ayres, M.G., Bilal, M., Jones, R.W., Slentz, L.W., \& Tartir, M. (1982). Hydrocarbon habitat in marine producing areas, Saudi Arabia. American Association of Petroleum Geologists Bulletin, 66(1):1-9.

Bahman, F.K. (2004). Geochemical studies and source rock potential of Lower Cretaceous (Upper Hith, Sulaiy, Lower Minagish) formations in Kuwait. Unpublished MSc thesis in geology, Kuwait University. Pp. 165.

Beydoun, Z.R. (1991). Arabian plate hydrocarbon geology and potential- A plate tectonic approach, American Association of Petroleum Geologists, Tulsa, USA, Pp. 77.

Bjorlykke, K. (1989). Sedimentology and Petroleum Geology. Heidelberg, Springer-Verlag, Berlin. Pp. 363.

Chung, H.M., Rooney, M.A., Toon, M.B. \& Claypool, G.E. (1992). Carbon isotopic composition of marine crude oils. American Association of Petroleum Geologists Bulletin, 76:1000-1007. 
Emery, D. \& Robinson, A. (1993). Inorganic geochemistry, application to Petroleum Geology. Blackwell Scientific Publications, London. Pp. 254.

Farrington, J.W., Davis, A.C., Tarafa, M.E., McCaffrey, M.A., \& Whelan, J. (1988). Bitumen molecular maturity parameters in the Ikpikpuk well, Alaska North Slope. Organic Geochemistry, 13:303-310.

Hans, G.B. (1984). Sedimentological interpretation of a sedimentary sequence in Kuwait, Arabian Gulf. Kuwait Journal of Science, 11:85-94.

Haq, B.U., Hardenbol, J., \& Vail, P.R. (1988). Mesozoic and Cenozoic Chronostratigraphy and Cycles of Sea Level Change. In Wilgus, CK., Hastings, B.S., Kendall, C.G., St. C., Possamentier, Ross, C.A., VanWagoner (eds), Sea-Level Changes an Integrated Approach Society of Economic Paleontologists and Mineralogists Special Publication, 42, 71-108.

Hughes, W.B., Holba, A. G. \& Dzou, L.I.P. (1995). The Ratios of Dibenzothiophene to Phenanthrene and Pristane to Phytane as indicators of depositional environment and lithology of petroleum source rocks. Geochimica et Cosmochimica Acta, 59:3581-3598.

Hussain, F.A. (1983). Source rock identification in the State of Kuwait using wireline Logs. $5^{\text {th }}$ SPE Middle East Oil Show, Bahrain, SPE 15747:477-488.

Kaufman, R.L., Ahmed, A. S. \& Eslinger, R.J. (1990). Gas chromatography as a development and production tool for fingerprinting oils from individual reservoirs. Applications in the Gulf of Mexico. In: Proceeding of the 9th Annual Research Conference of the society of Economic Paleontologists and Mineralogists (D. Schumacher and B.F. Perkins, eds.), society of Paleontologists and Mineralogists, Tulsa, Oklahoma, Pp. 263-82.

Kinghorn, R.R.F. \& Rahman, M. (1983). Specific gravity as a kerogen type and maturation indicator with special reference to amorphous kerogens. Journal of Petroleum Geology, 6:179194.

Moldowan, J.M., \& Peters, K.E. (1991). Effects of Source, Thermal maturity and biodegradation on the distribution and isomerization of Homohopanes in petroleum: Organic Geochemistry, 17:47-61.

Moldowan, J.M., Seifert, W.K. \& Gallegos, E.J. (1985). Relationship between petroleum composition and depositional environment of petroleum source rocks, American Association of Petroleum Geologists Bulletin, 69:1255-1268.

Murris, R.J. (1980). Middle East: stratigraphic evaluation and oil habitat. American Association of Petroleum Geologists Bulletin, 64(5):597-618.

Peters, K.E., Walters, C.C. \& Moldowan, J.M. (2005). The biomarker guide volume 1 and 2 biomarkers and isotopes in petroleum exploration and earth history, Cambridge University Press., The United Kingdom. Pp. 492.

Peters, K.E. (1986). Guidelines for evaluating petroleum source rocks using program pyrolysis. In: Beaumont, E.N., Forest, N.H. (Eds.), Geochemistry, AAPG Treaties of Petroleum Geology. Reprint Series 8, Pp. 392-403.

Peters, K.E., \& Moldowan, J.M. (1993). The biomarker guides. Prentice-Hall, Englewood Cliffs, NJ, Pp. 363. 
Radke, M. \& Welte, D.H. (1983). The Methylphenanthrene Index (MPI): a maturity parameter based on aromatic hydrocarbons. In: advance in organic geochemistry 1981 (M. Bijotoy, C. Albrecht, C. Cornford et al., eds). John Wiley \& Sons, New York, Pp. 504-11.

Radke, M., Welte, D.H. \& Willsch, H. (1982). Geochemical study of a well in the Western Canada Basin: relation of Aromatic distribution pattern to maturity of organic matter. Geochimica Cosmochimica Acta, 46:1-10.

Seifert, W.K. \& Moldowan, J.M. (1980). The effect of thermal stress on source-rock quality as measured by Hopane Stereochemistry. Physics and Chemistry of the Earth, 12:229-37.

Shah, S.B.A. \& Ahmed, A. (2018). Hydrocarbon source rock potential of Paleocene and Jurassic deposits in the Panjpir oilfield subsurface, Punjab Platform, Pakistan. Arabian Journal of Geosciences, 11(20), 607.

Shah, S.B.A. \& Ahmed, A. (2020). Evaluation of Ranikot Sandstone Formation, Punjab Platform Basin Pakistan. Journal of the Geological Society of India, 95(4):403-406.

Sharland, P.R., R. Archer, D.M. Casey, R. B. Davies, S. H. \& Hall, A. P. (2001). Arabian plate sequence stratigraphy. GeoArabia, Special Publication, 2, Pp. 371.

Sofer, Z. (1984). Stable carbon isotope compositions of crude oils: application to source depositional environment and petroleum alteration. American Association of Petroleum Geologists Bulletin, 68(1):31-49.

Sofer, Z., Zumberge, J.E. \& Lay, V. (1986). Stable carbon isotopes and biomarkers as tools in understanding genetic relationship, maturation, biodegradation, and migration of crude oils in the Northern Peruvian Oriente (Maranon) basin. Organic Geochemistry, 10:377-389.

Tissot, B.P. \& Welte, D.H. (1984). Petroleum formation and occurrence. Springer-Verlag, New York. Pp. 699.

Tucker, M.E. (1981). Sedimentary petrology an introduction, Blackwell Scientific Publications, London. Pp. 252.

Warsi, E.K. (1989). Gravity bases in the State of Kuwait. Kuwait Journal of Science 16, 1989: 433-446.

Submitted: $29 / 07 / 2020$

Revised: $\quad 24 / 02 / 2021$

Accepted: $07 / 03 / 2021$

DOI: $10.48129 / \mathrm{kjs} . v 49 \mathrm{i} 1.10277$ 